\title{
Pengaruh Kompetensi, Motivasi Kerja dan Lingkungan Kerja Terhadap Kinerja Pustakawan Pengadilan Agama di Sulawesi Selatan dan Barat
}

\author{
Anniswaty Hafid1, Salim Basalamah'2, Noer Jihad Saleh ${ }^{3}$ \\ ${ }_{1}^{1}$ Pengadilan Tinggi Agama Makassar, Mahasiswa Magister Manajemen, Program Pascasarjana Universitas Muslim Indonesia \\ 2,3 Fakultas Ekonomi dan Bisnis, Universitas Muslim Indonesia
}

Email Korespondensi: anniswatyhafid@gmail.com

\begin{abstract}
Abstrak
Tujuan penelitian ini dilakukan untuk mengetahui dan menganalisis pengaruh kompetensi, motivasi kerja, dan lingkungan kerja terhadap kinerja tenaga perpustakaan di Sulawesi Selatan. Populasi dalam penelitian ini pustakawan Pengadilan Agama di Sulawesi Selatan Barat dengan jumlah sampel sebanyak 56 orang. Metode dalam pengumpulan data dalam penelitian ini adalah observasi, wawancara, kuisioner dan dokumentasi. Metode analisis data menggunakan metode deskriptif dan metode kuantitatif yaitu dengan analisis regresi linier berganda yang digunakan untuk mengukur pengaruh kompetensi, motivasi kerja dan lingkungan kerja terhadap kinerja pustakawan Pengadilan Agama di Sulawesi Selatan/Barat. Berdasarkan uji F variabel bebas (kompetensi, motivasi kerja dan lingkungan kerja) secara bersama-sama memiliki pengaruh positif dan signifikan terhadap variabel terikat (kinerja pustakawan). Melalui pengujian koefisien korelasi (R) diperoleh bahwa korelasi atau hubungan antara kompetensi, motivasi kerja dan lingkungan kerja terhadap kinerja pustakawan sebesar 58,7\% dan lingkungan kerja merupakan faktor yang paling dominan mempengaruhi kinerja pustakawan Pengadilan Agama di Sulawesi Selatan/Barat.
\end{abstract}

Kata Kunci: Kompetensi, Motivasi, Lingkungan Kerja, Kinerja Tenaga Perpustakaan

\section{Pendahuluan}

Perkembangan dunia perpustakaan, ilmu pengetahuan dan teknologi merupakan tantangan bagi sebuah perpustakaan dalam mengikuti perkembangan ilmu pengetahuan pada zaman ini. Pada saat ini telah banyak ditemukan teknologi untuk menunjang proses berjalannya perpustakaan akan tetapi jika tidak diikuti oleh perkembangan sumber daya manusia yang handal akan percuma sebab dalam penggerak perpustakaan yang paling utama adalah sumber daya manusianya haruslah terpilih dan terlatih. Perpustakaan merupakan satuan kerja organisasi non-profit yang bertujuan sebagai sarana penyaluran informasi bagi pengguna perpustakaan. Pada sebuah perpustakaan, kesuksesan atau kegagalan dalam pelaksanaan tugas dan penyaluran informasinya dipengaruhi oleh sumber daya manusia. Hal ini sejalan dengan yang dikemukakan oleh Lasa (2008:26) "Maju mundurnya perpustakaan tergantung pada kualitas sumber daya manusia. Secara umum, sumber daya yang harus dimiliki perpustakaan terdiri atas sumber daya manusia dan sumber daya non manusia. Sumber daya manusia dapat dilihat dari perspektif politik, kultural dan administrasi. Sumber daya manusia merupakan faktor yang paling dominan jika dibandingkan dengan sumber-sumber daya yang lain dalam suatu perpustakaan. Sumber daya manusia merupakan unsur utama dalam pencapaian keberhasilan perpustakaan".

Sumber daya manusia (SDM) merupakan faktor yang sentral dalam sebuah Lembaga, termasuk di dalamnya perpustakaan. Apapun bentuk serta tujuannya, Lembaga dibuat berdasarkan berbagai visi untuk kepentingan manusia. Dalam pelaksanaan misinya, Lembaga dikelola dan diatur oleh manusia sebagai sumber daya yang strategis dalam kegiatan institusi maupun organisasi. Tanpa adanya faktor SDM dalam suatu perpustakaan, tidak akan mungkin perpustakaan tersebut dapat berkembang dan 
maju sesuai dengan yang diharapkan. Keberhasilan dalam mencapai tujuan perpustakaan sangat ditentukan oleh kinerja pustakawan atau pengelola perpustakaannya.Perpustakaan yang maju dan berkembang harus memiliki manajemen yang efektif. Peningkatan kinerja dalam manajemen yang efektif dapat dilakukan dengan cara mendukung pustakawannya agar memiliki kompetensi yang tinggi. Rendahnya kompetensi akan memunculkan ketidak mampuan dari pustakawan dalam bekerja yang akan mempengaruhi kinerja mereka, sehingga menghambat tujuan organisasi.

Kinerja adalah salah satu hasil kerja secara kualitas dan kuantitas yang dicapai oleh seseorang dalam melaksanakan tugasnya sesuai dengan tanggungjawab yang diberikan kepadanya Mangkunegara, (2006:9). Peningkatan kinerja merupakan hal terpenting yang diinginkan baik oleh pegawai maupun oleh Organisasi. Organisasi menginginkan kinerja pegawai yang optimal untuk kepentingan peningkatan hasil kerja dan keuntungan organisasi. Di sisi lain, pegawai berkepentingan untuk pengembangan diri dan promosi pekerjaan. Untuk memenuhi kedua keinginan tersebut, maka dibutuhkan sistem manajemen kinerja yang baik (Bangun, 2012:230). Perpustakaan Pengadilan Agama memberikan layanan dilingkungan Pengadilan Agama terutama untuk Hakim dan Panitera serta tenaga administrasi pengadilan dan warga masyarakat umum yang memerlukan informasi tentang hukum dan peradilan. Perpustakaan Pengadilan harus menyediakan semua bahan hukum yang diperlukan oleh Hakim dan Pejabat Pengadilan lainnya untuk penyelesaian suatu perkara. Untuk dapat menunjang pelaksanaan tugas-tugas peradilan secara berdaya guna dan berhasil guna diperlukan adanya perpustakaan Pengadilan yang baik pada semua Lembaga Pengadilan Agama yang tentunya dikelola oleh para pustakawan yang berkompeten dan berkinerja yang baik.

Perpustakaan Pengadilan Agama di Sulawesi Selatan Barat merupakan perpustakaan khusus Lembaga yang memberikan layanan kepada pemustaka di lingkungannya dan secara terbatas memberikan layanan kepada pemustaka di luar lingkungannya. Demi mendukung peningkatan pelayanannya tersebut, Perpustakaan Pengadilan Agama di Sulawesi Selatan/Barat telah memiliki SDM yang berjumlah 56 orang pengelola perpustakaan atau pustakawan. Mereka berasal dari berbagai latar belakang pendidikan, seperti ilmu perpustakaan, hukum, ekonomi, agama dan komunikasi. Bagi Perpustakaan Pengadilan Agama di Sulawesi Selatan Barat, masalah kinerja adalah masalah yang menarik untuk dibahas dan juga merupakan isu strategis bagi Lembaga Pengadilan Agama dalam program perencanaan sumber daya manusia. Banyak aspek internal maupun eksternal yang mendukung terciptanya kinerja yang efektif dan efisien dalam suatu Lembaga. Hal-hal yang nampaknya mempengaruhi upaya peningkatan kinerja yang efektif dan efisien adalah kompetensi dan motivasi kerja.

Pertama, kompetensi yang dimiliki oleh pustakawan sangat diperlukan dalam meningkatkan kinerja lembaga Peradilan Agama. Kompetensi berarti pengalaman kerja, pendidikan, pengetahuan dan keterampilan. Adapun pendapat yang dikemukakan oleh Ricky Alamsyah (2009:25) bahwa kompetensi terdiri dari sejumlah perilaku kunci yang dibutuhkan untuk melaksanakan peran tertentu untuk menghasilkan prestasi atau kinerja yang memuaskan, penentuan kompetensi yang dibutuhkan tentunya akan dapat dijadikan sebagai dasar evaluasi kinerja karyawan. Salah satu upaya instansi atau lembaga dalam mempertahankan kinerja pegawai adalah dengan cara memperhatikan kompetensi pegawai. Menurut Liestyono dan Purwaningdyah (2008) kompetensi merupakan pengetahuan, keterampilan, dan kemampuan yang dikuasai oleh seseorang yang telah menjadi bagian dari dirinya, sehingga ia dapat melakukan perilaku-perilaku kognitif, afektif, dan psikomotorik dengan sebaikbaiknya. Menurut Simanjuntak (2005:113) kompetensi dapat memperdalam dan memperluas kemampuan kerja. Semakin sering seseorang melakukan pekerjaan yang sama, semakin terampil dan semakin cepat pula menyelesaikan pekerjaan tersebut. Semakin banyak macam pekerjaan yang dilakukan seseorang, pengalaman kerjanya semakin kaya dan luas, dan memungkinkan peningkatan kerjanya. Sudarmanto (2009:32) mengatakan kompetensi sebagai atribut kualitas SDM berpengaruh signifikan terhadap kinerja individu.

Kompetensi menjelaskan apa yang dilakukan pegawai di tempat kerja pada berbagai tingkatan dan memperinci standar masing-masing tingkatan, mengindentifikasi karakteristik pengetahuan dan keterampilan yang diperlukan individu yang memungkinkan menjalankan tugas dan tanggung jawab secara efektif sehingga mencapai standar kualitas profesional dalam bekerja dan menghasilkan kinerja yang baik (Wibowo, 2009). Kompetensi pegawai dapat tercapai dengan cara memberikan pelatihan kepada pegawai yang sesuai dengan kebutuhan pekerjaannya dan tujuan organisasi. Kedua, motivasi kerja merupakan salah satu aspek yang sangat penting dalam menentukan perilaku seseorang, termasuk perilaku kerja sebagaimana dikemukakan oleh Rivai (2009:837). Motivasi adalah serangkaian 
sikap dan nilai-nilai yang mempengaruhi individu untuk mencapai hal yang spesifik seuai dengan tujuan individu. Sikap dan nilai tersebut merupakan sesuatu yang memberikan kekuatan untuk mendorong individu bertingkah laku dalam mencapai tujuan. Dorongan tersebut terdiri dari dua komponen, yaitu arah perilaku (kerja untuk mencapai tujuan), dan kekuatan perilaku (seberapa kuat usaha individu dalam bekerja).

Kinerja dapat dilihat dari seberapa besar mereka dapat bekerja secara baik dan menghasilkan pekerjaan secara tepat, cermat, efektif dan efisien. Usaha dalam meningkatkan kompetensi dan motivasi kerja akan menghasilkan kinerja pustakawan yang tinggi sehingga dapat dengan cepat dan efisien menyelesaikan pekerjaannya, serta dapat dengan mudah memenuhi sasaran. Namun hal tersebut terkadang tidak berjalan seperti yang diharapkan, karena adanya hambatan pustakawan dalam mencapai kinerja yang tinggi. Hal ini biasa disebabkan oleh kurang percaya diri, kurang mandiri, skill yang belum memadai, motivasi diri yang belum dapat melepaskan pola struktural artinya melaksanakan kegiatan didasarkan atas instruksi atau deskripsi tugas struktural. Hal inilah yang menjadi indikasi adanya penurunan kinerja sehingga berdampak pada perkembangan perpustakaan.

Terkait dengan hal tersebut, peneliti melakukan wawancara awal dengan beberapa Pimpinan Pengadilan Agama di Sulawesi Selatan Barat yang mengemukakan bahwa selama ini kinerja pengelola perpustakaan atau pustakawannya belum sepenuhnya baik. Hal ini dilihat masih ada pustakawan yang belum mampu mengerjakan tugas sesuai dengan tuntutan perpustakaan. Selain itu adanya kendala yang dihadapi beberapa pengelola perpustakaan atau pustakawan salah satunya faktor usia yang membuat kinerja mereka sedikit menurun. Faktor lainnya adalah tidak semua pustakawan mendapatkan kesempatan untuk mengikuti kegiatan pelatihan dan pendidikan lanjutan untuk peningkatan kualitas diri, sehingga menyebabkan mereka tidak mahir dalam mengelola perpustakaan sesuai dengan standar yang telah ditetapkan. Beberapa faktor-faktor di atas menyebabkan kinerja menurun dan berimplikasi juga pada kompetensi dan motivasi kerja pustakawan saat ini belum sepenuhnya optimal.

Ketiga, lingkungan kerja mempengaruhi kinerja tenaga pustakawan. Lingkungan kerja dalam suatu organisasi sangat penting untuk diperhatikan. Lingkungan kerja mempunyai pengaruh langsung terhadap pustakawan yang melaksanakan pekerjaannya. Lingkungan kerja yang baik tentu akan memuaskan bagi pustakawan, maka kinerja yang dihasilkan juga baik. Sebaliknya jika lingkungan kerja tidak memadai akan dapat menurunkan motivasi dan semangat kerja pada akhirnya menurunkan kinerja dari pustakawan itu sendiri. Kondisi lingkungan kerja yang baik jika manusia yang ada di dalamnya dapat melaksanakan kegiatan dengan optimal, sehat, aman dan nyaman. Nitisemito, A.S. (2000:183) menyebutkan lingkungan kerja sebagai segala sesuatu yang ada disekitar pegawai dan dapat mempengaruhi dirinya dalam menjalankan tugas yang dibebankan. Lingkungan kerja terdiri dari lingkungan fisik dan non fisik yang melekat pada pegawai dan dapat mempengaruhi dirinya dalam menjalankan tugas yang dibebankan.

Berkaitan dengan lingkungan kerja, Perpustakaan Khusus Pengadilan Agama, saat ini Pengadilan Agama di Sulawesi Selatan Barat telah memiliki ruangan tersendiri namun masih perlu tata kelola yang baik, dari yang peneliti amati fasilitas, sarana dan prasarana perpustakaan belum memadai serta pengelolaan koleksi yang belum memenuhi standar perpustakaan khusus yang telah ditetapkan oleh Undang-Undang Republik Indonesia Nomor 43 Tahun 2007 tentang Perpustakaan, Peraturan Pemerintah Republik Indonesia Nomor 24 Tahun 2014 tentang Perpustakaan dan Surat Keputusan Ketua Mahkamah Agung Republik Indonesia Nomor 85/KMA/SK/V/2014 tentang Pengelolaan Perpustakaan di lingkungan Mahkamah Agung Republik Indonesia dan 4 (Empat) Lingkungan Peradilan. Pustakawan akan mampu melaksanakan kegiatannya dengan baik, sehingga dicapai suatu hasil yang optimal apabila diantaranya ditunjang oleh kondisi liingkungan yang diserta fasilitas kerja yang memadai untuk menunjang kinerjanya.

Beberapa alasan di atas, menjadi pijakan awal dari peneliti untuk melakukan penelitian lebih mendalam lagi, hal ini disebabkan peneliti belum mengetahui secara pasti pengaruh kompetensi, motivasi kerja dan lingkungan kerja terhadap kinerja pustakawan Pengadilan Agama di Sulawesi Selatan/Barat. Adapun tujuan penelitian ini yaitu untuk membuktikan keadaan sebenarnya yang ada di lapangan agar memperoleh gambaran mengenai ada tidaknya pengaruh kompetensi, motivasi kerja dan lingkungan kerja terhadap kinerja pustakawan Pengadilan Agama di Sulawesi Selatan/Barat. Analisis ini perlu dilakukan untuk melihat pengaruh kompetensi, motivasi kerja dan lingkungan kerja pustakawan agar kinerja pustakawan lebih optimal lagi ke depannya. 
Uraian di atas yang menjadi alasan bagi peneliti perlunya melakukan penelitian di Perpustakaan Pengadilan Agama di Sulawesi Selatan/Barat.

Tabel 1. Rumusan dan Tujuan Penelitian

\begin{tabular}{|l|ll|}
\hline \multicolumn{2}{|c|}{ Rumusan Masalah } & \multicolumn{1}{c|}{ Tujuan Penelitian } \\
\hline 1. $\begin{array}{l}\text { Apakah kompetensi berpengaruh terhadap } \\
\text { kinerja pustakawan Pengadilan Agama di }\end{array}$ & 1. $\begin{array}{l}\text { Menganalisis pengaruh kompetensi } \\
\text { terhadap kinerja pustakawan Pengadilan } \\
\text { Sulawesi Selatan/Barat? }\end{array}$ & Agama di Sulawesi Selatan/Barat? \\
2. Apakah motivasi kerja berpengaruh terhadap \\
$\begin{array}{l}\text { kinerja pustakawan Pengadilan Agama di } \\
\text { Sulawesi Selatan/Barat? }\end{array}$
\end{tabular}

\section{Tinjauan Pustaka}

\section{A. Kompetensi}

Kompetensi merupakan kemampuan seseorang dalam melaksanakan kewajiban-kewajiban secara bertanggung jawab dan layak. Wibowo (2012:323), mengemukakan kompetensi adalah suatu kemampuan untuk melaksanakan atau melakukan suatu pekerjaan atau tugas yang dilandasi atas keterampilan dan pengetahuan serta di dukung oleh pengalaman kerja dan sikap yang dituntut oleh pekerjaan tersebut. Dengan demikian, kompetensi menunjukkan keterampilan atau pengetahuan yang dicirikan oleh profesinalisme dalam suatu bidang tertentu sebagai sesuatu yang terpenting, sebagai unggulan bidang tersebut. Sutrisno (2011: 203) menjelaskan bahwa pengertian kompetensi dalam organisasi publik maupun privat sangat diperlukan terutama untuk menjawab tuntutan organisasi, dimana adanya perubahan yang sangat cepat, perkembangan masalah yang sangat kompleks dan dinamis serta ketidakpastian masa depan dalam tatanan kehidupan masyarakat. Kompetensi adalah suatu kemampuan yang dilandasi oleh keterampilan dan pengetahuan yang didukung sikap dan pengalaman kerja serta penerapannya dalam melaksanakan tugas dan pekerjaan di tempat kerja yang mengacu pada persyaratan kerja yang ditetapkan.

Darsono dan Siswandoko (2011:123) kompetensi adalah perpaduan keterampilan, pengetahuan, kreativitas dan sikap positif terhadap pekerjaan tertentu yang diwujudkan dalam kinerja. Kompetensi merupakan karakter seseorang yang mampu menghasilkan kinerja terbaik dibanding orang lain. Berdasarkan pendapat di atas mengenai kompetensi dapat disimpulkan kompetensi merupakan kemampuan seseorang dalam melakukan atau melaksanakan pekerjaannya yang didasari oleh pengalaman kerja, pendidikan, pengetahuan, dan keterampilan yang ada dalam diri untuk menghasilkan suatu kinerja yang diharapkan. Sudarmanto (2009: 47) mendefenisikan kompetensi sebagai pengetahuan keahlian, kemampuan, atau karakteristik pribadi individu yang mempengaruhi secara langsung kinerja pekerjaan. Kompetensi menggambarkan dasar pengetahuan dan standar kinerja yang dipersyaratkan agar berhasil menyelesaikan suatu pekerjaan atau memegang suatu jabatan.

Kompetensi yaitu kemampuan, wewenang dan kecakapan. Dari segi etimologi, kompetensi berarti segi keunggulan, keahlian dari perilaku seseorang pegawai atau pimpinan yang mana punya suatu pengetahuan, perilaku dan keterampilan yang baik. Karakteristik dari kompetensi yaitu sesuatu yang menjadi bagian dari karakter pribadi dan menjadi bagian dari perilaku seseorang dalam melaksanakan suatu tugas pekerjaan (Mankunegara, 2009:5), Jadi, kompetensi merupakan kemampuan melaksanakan pekerjaan atau tugas yang didasari keterampilan maupun pengetahuan dan didukung oleh pengalaman kerja yang ditetapkan oleh pekerjaan. Kompetensi menunjukan pengetahuan, keterampilan dan sikap tertentu dari suatu profesi dalam ciri keahlian tertentu, yang menjadi ciri dari seorang profesional. Karena bawaan keprofesionalan dari seorang karyawan membawa positif bagi karyawan. Secara terminologi kompetensi merupakan atribut untuk melekatkan sumber daya manusia yang berkualitas atau unggul. Atribut mengacu pada karakteristik tertentu. Ada yang menginteprestasikan kompetensi sepadan dengan kemampuan dan kecakapan. Ada lagi yang mengintepretasikan sepadan dengan keterampilan, pengetahuan dan berpendidikan tinggi.

Menurut Spencer and Spencer (2010:10) beberapa aspek yang terkandung dalam aspek kompetensi adalah sebagai berikut: a) Pengetahuan (Knowledge), knowledge adalah pengetahuan informasi yang 
dimilki seseorang untuk bidang tertentu, pengetahuan merupakan kompetensi yang kompleks. Tes pengetahuan mengukur kemampuan peserta untuk memilih jawaban yang paling benar tetapi tidak bisa melihat apakah seseorang dapat melakukan pekerjaan berdasarkan pengetahuan yang dimilikinya. b) Sikap (Self Concept), self Concept adalah sikap dan nilai-nilai yang dimilki seseorang. Sikap dan nilai diukur melalui tes kepada responden untuk mengetahui nilai yang dimilki seseorang dan apa yang menarik bagi seseorang untuk melakukan sesuatu. c) Watak (Traits), traits adalah watak yang membuat orang untuk berperilaku atau bagaimana seseorang merespon sesuatu dengan cara tertentu. Sebagai contoh seperti percaya diri, kontrol diri, ketabahan atau daya tahan. d) Kemampuan/keterampilan (Skills), skills adalah kemampuan melaksanakan suatu tugas tertentu baik secara fisik maupun mental. Dengan mengetahui tingkat kompetensi maka perencanaan sumber daya manusia akan lebih baik hasilnya. e) Minat (Interest), kecenderungan seseorang untuk melakukan suatu perbuatan, misalnya melakukan aktivitas.

\section{B. Motivasi}

Motivasi berasal dari kata motivation yang berarti "menggerakkan". Motivasi merupakan hasil sejumlah proses yang bersifat internal atau eksternal bagi seorang individu, yang menyebabkan timbulnya sikap entutiasme dan persistensi dalam hal melaksanakan kegiatan. Seberapa kuat motivasi yang dimiliki individu akan banyak menentukan terhadap kualitas perilaku yang ditampilkannya baik dalam konteks belajar, bekerja maupun dalam kehidupan lainnya. Defenisi motivasi sebagai daya dorong yang mengakibatkan seseorang mau dan rela untuk menggerakan kemampuan, tenaga, dan waktunya dalam rangka pencapaian tujuan yang telah ditentukan sebelumnya dikemukan oleh Sondang (2011:135), sedangkan menurut Azwar (2009:15) motivasi adalah rangsangan, dorongan ataupun pembangkit tenaga yang dimilki seseorang atau kelompok masyarakat yang mau berbuat dan bekerjasama secara optimal dalam melaksanakan sesuatu yang telah direncanakan untuk mencapai tujuan yang telah ditetapkan.

a) Teori Kebutuhan Maslow, teori motivasi yang sekarang banyak dirujuk orang adalah teori kebutuhan. Teori ini beranggapan bahwa tindakan manusia pada hakekatnya adalah untuk memenuhi kebutuhannya. Seperti teori yang dikemukakan oleh Maslow yang dikuti Mangkunegara (2009:93), mengemukakan bahwa ada 5 (lima) jenjang kebutuhan pokok manusia: 1) Kebutuhan Fisologi (Psysiological needs), kebutuhan dasar untuk menunjang kehidupan. Manifestasi kebutuhan ini tampak dari : sandang, pangan dan papan. Kebutuhan ini merupakan kebutuhan primer. 2) Kebutuhan Keamanan (Safety needs), manifestasi kebutuhan ini adalah kebutuhan akan keamanan, kebutuhan fisilogis, puas dan tidak mengendalikan pikiran lagi dan perilaku, kebutuhan keamanan dapat menjadi aktif. 3) Kebutuhan Social (Social needs), manifestasi kebutuhan ini antara lain tampak pada kebutuhan akan perasaan diterima oleh orang lain, kebutuhan untuk maju dan tidak gagal juga kekuatan untuk ikut serta. 4) Kebutuhan akan penghargaan/prestise (Esteem needs), semakin tinggi status, maka semakin tinggi pula prestisenya. Prestise dan status ini dimanfestasikan dengan banyak cara misalnya : mobil mewah, kamar kerja full AC dan lain-lain. 5) Kebutuhan Aktualisasi Diri (Self Actualization needs), manifestasi kebutuhan ini adalah keinginan untuk mengembangkan kapasitas mental dan kapasitas kerja melalui on the job training. Of the job training, seminar, konferensi, pendidikan akademis dan lain-lain.

b) Teori Dua Faktor Hezberg, teori motivasi 2 (dua) faktor berdasarkan atas pembagian hierarki Maslow menjadi kebutuhan atas dan bawah menurut Hezberg (2009:115) hanya kondisi yang memungkinkan pemenuhan kebutuhan atas yaitu penghargaan dan aktualisasi diri sendiri akan meningkatkan motivasi kerja. Sebuah organisasi harus memungkinkan karyawannya memenuhi kebutuhan tingkat bawah melalui kerja, tetapi ini adalah cara untuk mempertahankan karyawan tersebut di organisasi, bukan untuk mempengaruhi motivasi kerjanya. Dari beberapa uraian pengertian motivasi di atas dapat diambil kesimpulan bahwa konsep motivasi adalah keseluruhan pemberian dorongan bekerja dari atasan kepada bawahan sedemikian rupa sehingga mereka bersedia memberikan yang terbaik bagi dirinya dan baik waktu, tenaga dan keterampilannya demi tercapainya tujuan organisasi.

c) Teori Harapan Victor H.Vroom, di dalam buku yang berjudul "Work and Motivator" mengetengahkan suatu teori yang disebut "Teori Harapan" yang ditulis oleh Vroom (2009:141). Menurut teori ini, motivasi merupakan akibat suatu hasil dari yang ingin dicapai oleh seseorang dan perkiraan yang diinginkannya itu. Artinya, apabila seseorang sangat menginginkan sesuatu dan jalan tampaknya terbuka, maka yang bersangkutan akan berupaya untuk mendapatkannya. Dinyatakan 
dengan cara yang sangat sederhana, teori harapan berkata bahwa seseorang menginginkan sesuatu dan harapan untuk memperoleh sesuatu itu cukup besar, yang bersangkutan akan sangat terdorong untuk memperoleh hasil yang diinginkannya itu. Sebaliknya, jika harapan memperoleh hal yang diinginkannya itu tipis, maka motivasi untuk mendapatkan pun menjadi rendah. Di kalangan ilmuan dan para praktisi manajemen sumber daya manusia teori harapan ini mempunyai daya tarik tersendiri karena penekanan tentang pentingnya bagian kepegawaian membantu para pegawai dalam menentukan hal-hal yang diinginkannya serta menunjukkan cara-cara yang paling tepat untuk mewujudkan keinginannya itu.

Menurut Hasibuan (2003) yang dikutip Soekidjo (2005:125) mengemukakan bahwa : motivasi di dalam suatu organisasi mempunyai maksud dan tujuan yang sangat luas dalam rangka pengembangan organisasi tersebut, antara lain : a) Meningkatkan gairah dan semangat kerja pegawai atau karyawan; b) Meningkatkan kepuasan kerja karyawan, yang akhirnya meningkatkan kinerjanya; c) Meningkatkan produktifitas karyawan; d) Meningkatkan loyalitas dan integritas karyawan; e) Meningkatkan kedisiplinan karyawan; f) Meningkatkan kehadiran kerja karyawan Menurut Maslow yang dikutip Hasibuan (2003), menjelaskan bahwa motivasi kerja karyawan dipengaruhi oleh kebutuhan fisik, kebutuhan akan keamanan dan keselamatan, kebutuhan sosial, kebutuhan akan penghargaan diri, dan kebutuhan aktualisasi diri.

\section{Lingkungan Kerja}

Lingkungan kerja adalah tempat di mana karyawan melakukan aktivitas setiap harinya. Lingkungan kerja yang kondusif memberikan rasa aman dan memungkinkan karyawan untuk dapat bekerja optimal. Lingkungan kerja dapat mempengaruhi emosi karyawan. Jika karyawan tersebut akan betah dalam melakukan aktivitas, sehingga waktu kerja di pergunakan secara efektif. Lingkungan kerja itu mencakup hubungan kerja yang terbentuk antara sesama karyawan dan hubungan kerja antara bawahan dan atasan serta lingkungan fisik tempat karyawan bekerja. Menurut Nitisemito (dalam Intaghina 208:97) lingkungan kerja adalah segala sesuatu yang ada di sekitar pekerja yang dapat mempengaruhi dirinya dalam menjalankan tugas-tugasnya pada pengertian ini lingkungan kerja lebih dititikberatkan pada keadaan fisik.

Menurut Sukanto dan Indriyo (2000) lingkungan kerja adalah segala sesuatu yang ada disekitar pekerja yang dapat mempengaruhi pihak yang bersangkutan dalam bekerja. Lingkungan itu meliputi pengaturan penerangan, pengontrolan suara gaduh, pengaturan kebersihan dan pengaturan keamanan tempat kerja. Sedangkan Sihombing (2001), mendefenisikan bahwa lingkungan kerja adalah faktorfaktor diluar manusia baik fisik maupun non fisik. Menurut Suparti dalam Subroto (2005:83), menyatakan bahwa lingkungan kerja merupakan keadaan sekitar tempat kerja baik secara fisik maupun non fisik yang dapat memberikan kesan yang menyenangkan, mengamankan, menetramkan, dan betah dalam bekerja.

Lingkungan kerja dapat dibagi atas dua jenis yaitu, lingkungan kerja fisik dan lingkungan kerja non fisik. Menurut Robbins (2002:36) lingkungan kerja fisik juga merupakan faktor penyebab stress kerja pegawai yang berpengaruh pada prestasi kerja. Faktor-faktor yang mempengaruhi lingkungan kerja fisik adalah: a) Suhu, suhu adalah suatu variabel dimana terdapat perbedaan individual yang besar. Dengan demikian untuk memaksimalkan produktivitas, adalah penting bahwa pegawai bekerja di suatu lingkungan dimana suhu diatur sedemikian rupa sehingga berada diantara rentang kerja yang dapat diterima setiap individu. b) Kebisingan, bukti dari telaah-telaah tentang suara menunjukkan bahwa suara-suara yang konstan atau dapat diramalkan pada umumnya tidak menyebabkan penurunan prestasi kerja sebaliknya efek dari suara-suara yang tidak dapat diramalkan memberikan pengaruh negatif dan mengganggu konsentrasi pegawai. c) Penerangan, bekerja pada ruangan yang gelap dan samar-samar akan menyebabkan ketegangan pada mata. Intensitas cahaya yang tepat dapat membantu pegawai dalam memperlancar aktivitas kerjanya. Tingkat yang tepat dari intensitas cahaya juga tergantung pada usia pegawai. Pencapaian prestasi kerja pada tingkat penerangan yang lebih tinggi adalah lebih besar untuk pegawai yang lebih tua dibanding yang lebih muda. d) Mutu Udara, merupakan fakta yang tidak bisa diabaikan bahwa jika menghirup udara yang tercemar membawa efek yang merugikan pada kesehatan pribadi. Udara tercemar dapat mengganggu kesehatan pribadi pegawai. Udara yang tercemar di lingkungan kerja dapat menyebabkan sakit kepala, mata perih, kelelahan, lekas marah dan depresi.

Membina hubungan yang baik antara sesama rekan kerja, bawahan maupun atasan harus dilakukan karena kita saling membutuhkan. Hubungan kerja yang terbentuk sangat mempengaruhi 
psikologi pegawai. Lingkungan kerja adalah kekuatan yang mendorong semangat yang ada didalam maupun diluar dirinya baik itu berupa penghargaan (reward) maupun hukuman (punishment), sehingga Herberg dalam Luthans (2003) menyatakan bahwa pada manusia terdapat enam faktor pemuas yaitu: 1). Prestasi kerja yang diraih (achievement); 2). Pengakuan orang lain (recognition); 3). Tanggung jawab (responsibility); 4). Peluang untuk maju (advancement); 5). Kepuasan kerja itu sendiri (the work it self); 6). Pengembangan karier (the possibility). Perubahan lingkungan, baik lingkungan eksternal maupun internal akan mempengaruhi protean career, karena protean career harus mengikuti perubahan atau perkembangan agar seseorang bisa memperoleh kepuasan pribadi yang diharapkan. Dari asumsi-asumsi di atas, peneliti dapat menyimpulkan bahwa lingkungan kerja adalah (1) interaksi antar pegawai, (2) tempat kerja yang nyaman, (3) kesehatan dan keselamatan kerja.

\section{Kinerja}

Secara etimologi dalam Kamus Besar Bahasa Indonesia istilah kinerja berarti sesuatu yang dicapai, prestasi yang diperlihatkan, dan kemampuan kerja (Badudu: 1994). Soedarmayanti (2000:53) mengemukakan "kinerja dapat dinilai dari apa yang dilakukan oleh seorang pegawai dalam kerjanya". stilah kinerja berasal dari kata job performance atau actual performance (kinerja atau prestasi nyata) yang berkaitan dengan segala aktivitas dalam suatu organisasi kerja. Performance atau kinerja adalah hasil kerja yang dapat dicapai oleh seseorang atau sekompok orang dalam suatu organisasi, sesuai dengan tanggung jawab masing-masing, dalam rangka upaya mencapai tujuan organisasi bersangkutan secara legal, tidak melanggar hukum dan sesuai dengan moral maupun etika (Wahid, 2004:29). Kemudian mengenai kinerja (performance) diartikan pula oleh Simamora (2001:327) yaitu merupakan suatu pencapaian persyaratan pekerjaan tertentu yang akhirnya secara nyata dapat tercermin keluaran yang dihasilkan. Soetjipto (2002:7) menyebutkan istilah kinerja dan prestasi kerja yaitu: hasil kerja seseorang selama periode tertentu dibandingkan dengan berbagai kemungkinan, misalnya standar, target/sasaran. Menurut Mangkuprawira (2003:67), istilah kinerja berasal dari kata Job Performance atau Actual Performance (prestasi kerja atau prestasi sesungguhnya yang dicapai oleh seseorang). Pengertian kinerja (prestasi kerja) adalah hasil kerja secara kualitas dan kuantitas yang dicapai oleh seorang pegawai dalam melaksanakan tugasnya sesuai dengan tanggung jawab yang diberikan kepadanya.

Kinerja menurut Wibowo, (2012), Kinerja adalah melakukan pekerjaan dan hasil yang dicapai dari pekerjaan tersebut. Kinerja adalah tentang apa yang dikerjakan dan bagaimana cara mengerjakannya. Kinerja pegawai adalah tingkat pencapaian hasil kerja seorang pegawai dalam melaksanakan pekerjaan atau hasil kerja yang dicapai seorang pegawai dalam melaksanakan pekerjaan untuk pencapaian tujuan organisasi. Kesediaan dan keterampilan tidaklah cukup efektif untuk mengerjakan sesuatu pekerjaan tanpa pemahaman yang jelas tentang apa yang dikerjakan dan bagaimana mengerjakannya. Selanjutnya Robbins (2000) mengatakan bahwa kinerja sebagai fungsi interaksi antara kemampuan atau ability (A), motivasi atau motivation (M) dan kesempatan atau opportunity $(\mathrm{O})$, yaitu kinerja $=\mathrm{f}(\mathrm{A} \times \mathrm{M}$ $x$ O). Artinya kinerja merupakan fungsi dari kemampuan, motivasi dan peluang. Dengan demikian, kinerja ditentukan oleh faktor-faktor kemampuan, motivasi dan kesempatan.

Penilaian kinerja merupakan landasan penilaian kegiatan manajemen sumber daya manusia seperti perekrutan, seleksi, penempatan, pelatihan, penggajian, dan pengembangan karir. Kegiatan penilaian kinerja sangat erat kaitannya dengan kelangsungan organisasi. Berdasarkan uraian di atas dapat disimpulkan bahwa penilaian kinerja merupakan bagian integral dari proses penilaian yang meliputi: penerapan sasaran pengarahan dan dukungan atasan. Karyawan bersama atasan masingmasing dapat menetapkan sasaran dan standar kinerja yang harus dicapai dalam kurun waktu tertentu. Peningkatan kinerja karyawan perseorangan pada gilirannya akan mendorong kinerja sumber daya manusia secara keseluruhan.

Berdasarkan Peraturan Pemerintah Nomor 46 Tahun 2011 tentang penilaian prestasi kerja Pegawai Negeri Sipil menyatakan bahwa penilaian kinerja atau perilaku kerja meliputi aspek: a) Orientasi pelayanan, b) Integritas, c) Komitmen, d) Disiplin, e) Kerjasama, dan f) Kepemimpinan. Orientasi pelayanan adalah sikap dan perilaku kerja PNS dalam memberikan pelayanan terbaik kepada yang dilayani antara lain meliputi masyarakat, atasan, rekan sekerja, unit kerja terkait, dan/atau instansi lain. Integritas adalah kemampuan untuk bertindak sesuai dengan nilai, norma dan etika dalam organisasi. Komitmen adalah kemauan dan kemampuan untuk menyelaraskan sikap dan tindakan PNS untuk mewujudkan tujuan organisasi dengan mengutamakan kepentingan dinas daripada kepentingan diri sendiri, seseorang, dan/atau golongan. Disiplin adalah kesanggupan PNS untuk menaati kewajiban 
dan menghindari larangan yang ditentukan dalam peraturan perundang-undangan dan atau peraturan kedinasan yang apabila tidak ditaati atau dilanggar dijatuhi hukuman disiplin. Kerjasama adalah kemauan dan kemampuan PNS untuk bekerjasama dengan rekan sekerja, atasan, bawahan dalam unit kerjanya serta instansi lain dalam menyelesaikan suatu tugas dan tanggungjawab yang ditentukan, sehingga mencapai daya guna dan hasil guna yang sebesar-besarnya. Kepemimpinan adalah kemampuan dan kemauan PNS untuk memotivasi dan mempengaruhi bawahan atau orang lain yang berkaitan dengan bidang tugasnya demi tercapainya tujuan organisasi.

\section{E. Pustakawan}

Secara tradisional pengertian pustakawan adalah orang yang ahli mengelola koleksi buku dan bahan-bahan informasi lainnya, dan membantu pengguna untuk mengakses koleksi tersebut Feather \& Sturges (1997:252). Sedangkan Harrod $(1987 ; 145)$ mendefenisikan pustakawan sebagai orang yang mengelola perpustakaan dan isinya, menyeleksi buku-buku, dokumen dan bahan non buku untuk memenuhi kebutuhan pemakainya. Namun saat ini, pustakawan adalah manajer dan mediator dalam mengakses informasi untuk pengguna yang berasal dari berbagai bidang. Pustakawan tidak hanya mengakses melalui koleksi dan bahan-bahan informasi yang tersedia di perpustakaan tetapi juga melalui sumber-sumber informasi yang tersedia di luar perpustakaan yang dapat diakses secara global. Menurut Undang-Undang Republik Indonesia Nomor 43 Tahun 2007 tentang Perpustakaan disebutkan pustakawan adalah seseorang yang memiliki kompetensi yang diperolehnya melalui pendidikan dan/atau pelatihan kepustakawanan, serta mempunyai tugas dan tanggungjawab untuk melaksanakan pengelolaan dan pelayanan perpustakaan.

Kompetensi di lingkungan profesi pustakawan merupakan hal yang sangat positif bagi perkembangan SDM di bidang perpustakaan yang menunjukkan keseriusan terhadap pentingnya kualitas kerja yang tidak semata-mata didasarkan pada aturan baku kepegawaian. Kompetensi pustakawan dikelompokkan ke dalam dua jenis kompetensi yaitu kompetensi professional yaitu kemampuan yang didukung dengan pengetahuan yang luas tentang sumber-sumber infformasi, teknologi, manajemen dan penelitian serta kemmampuan untuk menggunakan pengetahuan tersebut sebagai dasar untuk menyelenggarakan layanan perpustakaan dan kompetensi personal yang lebih pada kemampuan individu dalam berkomunikasi dan bekerjasama untuk menciptakan nilai lebih dari penyelenggaraan perpustakaan. Selanjutnya dalam Undang-Undang No.43 Tahun 2007 pasal 29 Undang-Undang Nomor 43 Tahun 2007 diatur secara khusus prinsip umum tentang pustakawan:

1. pustakawan terdiri atas pustakawan dan tenaga teknis perpustakaan.

2. Pustakawan sebagaimana dimaksud pada ayat (1) harus memenuhi kualifikasi sesuai standar nasional perpustakaan.

Tugas tenaga teknis perpustakaan sebagaimana di maksud pada ayat (1) dapat dirangkap oleh pustakawan sesuai dengan kondisi perpustakaan yang bersangkutan. Ketentuan mengenai tugas, tanggungjawab, pengangkatan, pembinaan, promosi, pemindahan tugas dan pemberhentian pustakawan yang berstatus Pegawai Negeri Sipil dilakukan sesuai dengan peraturan perundangundangan. Ketentuan mengenai tugas, tanggung jawab, pengangkatan, pembinaan, promosi, pemindahan tugas dan pemberhentian pustakawan yang berstatus Non Pegawai Negeri Sipil dilakukan sesuai dengan peraturan yang ditetapkan penyelenggara perpustakaan yang bersangkutan.

Untuk memiliki SDM yang berkualitas di perpustakaan, perlu diperhatikan sejumlah karakteristik atau kompetensi professional yang harus dimiliki seorang pustakawan atau pustakawan, seperti yang dijelaskan dalam UU No. 43 Tahun 2007 bahwa "pustakawan adalah orang yang memiliki kompetensi, artinya adalah pustakawan yang mempunyai kecakapan, keterampilan dan pengetahuan guna memberikan yang terbaik bagi pemustaka" (Arif Surahman : 2009) Kompetensi menjadi kunci utama bagi pustakawan untuk lebih berperan dalam meningkatkan pelayanan perpustakaan. Adapun kompetensi professional seorang pustakawan menurut UU No. 43 Tahun 2007 dalam (Harmawan: 2008) adalah: a).memiliki komitmen untuk memberikan layanan terbaik.; b). mampu mencari peluang dan melihat kesempatan baru baik di dalam maupun di luar perpustakaan; c). berpandangan luas.; d). mampu mencari partner kerja; e). mampu menciptakan lingkungan kerja yang dihargai dan dipercaya; f). memiliki keterampilan bagaimana berkomunikasi yang efektif; g). dapat bekerjasama secara baik dalam suatu tim kerja. h). memiliki sifat kepemimpinan; i). mampu merencanakan, memprioritaskan dan memusatkan pada suatu yang kritis; j). memiliki komitmen untuk selalu belajar dan merencanakan 
pengembangan kariernya; k). mampu mengenali nilai kerjasama secara professional dan solidaritas; 1 ). memiliki sifat positif dan fleksibel dalam menghadapi perubahan.

Pengadaan atau rekruitmen pustakawan bisa berasal dari dua sumber, yaitu: (a) Sumber dari dalam (Internal), sumber internal diambil dari lingkungan organisasi sendiri. Biasanya kebijakan kepegawaian memberikan kesempatan lebih dahulu kepada pegawai yang ada daripada menerima pegawai baru. Hal ini dikarenakan sumber internal ada sumber yang baik, sebab telah mengetahui dan mengerti kondisi organisasi. Penggunaan sumber internal ini juga untuk memotivasi pegawai yang telah ada untuk meningkatkan prestasi, agar jika ada kekosongan bisa dipilih untuk mengisi kekosongan tersebut. (b) Informasi tentang kelayakan seseorang untuk dipromosikan dapat bersumber dari tiga hal yaitu, prestasi kerja sekarang, hasil penilaian atasan mengenai potensi yang bersangkutan, dan hasil berbagai tes serta berbagai teknik peilaian lain yang diselenggarakan oleh satuan kerja yang mengelola sumber daya manusia dalam organisasi (Siagian, S.P. 2002). (c) Sumber dari luar (Eksternal), sumber internal memang merupakan sumber yang baik, akan tetapi tidak selalu dapat memenuhi kebutuhan organisasi. Untuk itu diperlukan perekrutan tenaga yang tepat dari sumber eksternal. Rekruitmen tenaga dari luar di tempatkan pada posisi 'yang tidak penting. Apabila nanti yang bersangkutan menunjukkan prestasi yang baik dan memenuhi syarat lain yang dimungkinkan untuk menduduki posisi yang lebih penting.

\section{F. Kerangka Konseptual}

Dalam upaya meningkatkan kinerja, baik kinerja individu maupun kinerja kelompok, kompetensi, motivasi kerja, maupun lingkungan kerja adalah merupakan variabel yang signifikan dalam meningkatkan kinerja. Berikut ini adalah kerangka konseptual yang digunakan dalam penelitian ini adalah:

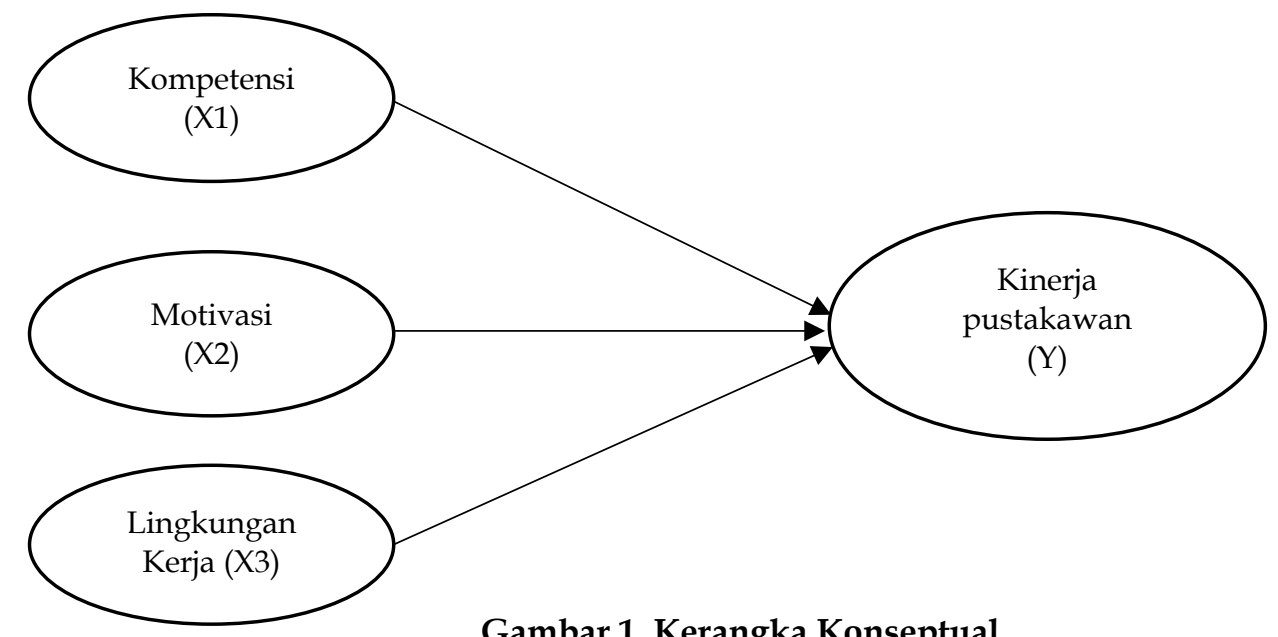

Gambar 1. Kerangka Konseptual

Hipotesis dapat diartikan sebagai pernyataan yang akan diteliti sebagai jawaban sementara dari suatu masalah. Berdasarkan kerangka pemikiran teoritis tersebut, maka diajukan hipotesis sebagai berikut :

H1 : Kompetensi berpengaruh positif dan signifikan terhadap kinerja pustakawan Pengadilan Agama di Sulawesi Selatan/Barat.

H2 : Motivasi berpengaruh positif dan signifikan terhadap kinerja Tenaga Perpustakaan Pengadilan Agama di Sulawesi Selatan/Barat.

H3 : Lingkungan Kerja berpengaruh positif dan signifikan terhadap kinerja pustakawan Pengadilan Agama di Sulawesi Selatan/Barat.

\section{Metode Penelitian}

Pendekatan yang digunakan dalam penelitian ini adalah pendekatan kualitatif serta pendekatan kuantitatif. Penelitian ini akan menjelaskan hubungan mempengaruhi dan dipengaruhi dari variabelvariabel yang akan diteliti, yaitu pengaruh kompetensi, motivasi kerja dan lingkungan kerja terhadap pustakawan. Pendekatan kuantitatif digunakan karena data yang akan digunakan untuk menganalisis pengaruh antar variabel dinyatakan dengan angka. Lokasi Penelitian ini dilaksanakan pada Perpustakaan Pengadilan Agama di Sulawesi Selatan / Barat. Lokasi ini dipilih dengan pertimbangan 
bahwa masalah yang diteliti adalah masalah yang berkaitan langsung dengan profesi peneliti, sehingga hasil penelitian yang diperoleh nantinya dapat diimplementasikan secara langsung untuk kepentingan lembaga Pengadilan Agama. Waktu penelitian dilakukan mulai dari pengajuan usulan penelitian, survey lapangan, penulisan proposal, pengumpulan data penelitian hingga hasil penelitian ditargetkan membutuhkan waktu selama 3 (tiga) bulan.

Adapun jenis data yang digunakan oleh penulis dalan penelitian ini adalah sebagai berikut: (a) Data Kualitatif, yaitu data yang bukan dalam bentuk angka-angka atau tidak dapat dihitung, dan diperoleh dari hasil wawancara dengan Ketua dan Wakil Ketua Pengadilan Agama di Sulawesi Selatan/Barat, Pejabat Struktural, Staf dan pustakawan serta informasi-informasi yang diperoleh dari pihak lain yang berkaitan dengan masalah yang diteliti. (b) Data Kuantitatif, adalah data yang diperoleh dalam bentuk angka-angka yang dapat dihitung, yang diperoleh dari kuesioner yang dibagikan dan berhubungan dengan masalah yang diteliti. Adapun sumber data yang digunakan penulis dalam penelitian ini adalah sebagai berikut: (a) Data primer, adalah data yang diperoleh penulis melalui observasi atau pengamatan langsung pada Perpustakaan Pengadilan Agama di Sulawesi Selatan/Barat, baik itu observasi, kuesioner dan wawancara secara langsung dengan Ketua atau Wakil Ketua, Pejabat Struktural dan Fungsional serta staf/Honorer Pengadilan Agama di Sulawesi Selatan/Barat. (b) Data sekunder merupakan data yang diperoleh tidak langsung, yaitu data tersebut diperoleh penulis dari dokumen-dokumen lembaga dan buku-buku literatur yang memberikan informasi kaitannya dengan penelitian.

Dalam penelitian ini menggunakan teknik pengumpulan data sebagai berikut: 1). Observasi, pengumpulan data dengan melakukan pengamatan langsung atas obyek penelitian yang dimaksud untuk mendapatkan gambaran yang jelas tentang keberadaan obyek penelitian dan kegiatan yang dilakukan. 2). Wawancara, proses memperoleh keterangan untuk tujuan penelitian dengan cara tanya jawab secara lisan sambil bertatap muka ataupun melalui via telepon dan media social (Whatshapp) dengan responden sehingga dapat diperoleh data dan informasi yang diperlukan mengenai obyek penelitian. 3). Kuisioner, kuisioner merupakan sejumlah pertanyaan tertulis yang digunakan untuk memperoleh informasi dari responden. Kuisioner dalam penelitian ini terdiri dari daftar pertanyaan maupun pernyataan yang dibagikan kepada responden dan digunakan untuk mengumpulkan data yang berkaitan dengan variabel kompetensi, motivasi kerja, lingkungan kerja dan kinerja pustakawan. Kuesioner yang digunakan dalam penelitian ini adalah angket tertutup yaitu kuesioner yang disusun dengan menyediakan pilihan jawaban yang lengkap, sehingga responden hanya memberikan jawaban yang telah sediakan. 4). Telaah Dokumen, pengambilan data yang diperoleh melalui telaah dokumendokumen terdapat pada lokasi penelitian maupun data-data yang didapat dari buku-buku yang terkait dengan obyek penelitian. Populasi penelitian ini adalah seluruh pustakawan yang terdiri dari penanggungjawab perpustakaan, pustakawan dan tenaga teknis Perpustakaan Pengadilan Agama di Sulawesi Selatan/Barat yang berjumlah yaitu 56 orang. Teknik pengambilan sampel yang digunakan adalah metode sensus yaitu mengambil seluruh populasi sasaran untuk dijadikan sampel.

Tabel 2. Jumlah Populasi dan Sampel Penelitian

\begin{tabular}{|c|c|c|}
\hline No & pustakawan & Jumlah \\
\hline 1 & Pustakawan & 7 \\
\hline 2 & Tenaga Teknis Perpustakaan & 49 \\
\hline & Total & $\mathbf{5 6}$ \\
\hline
\end{tabular}

Sumber: Sub Bagian Kepegawaian dan IT Pengadilan Tinggi Agama Makassar

Berdasarkan hipotesis yang diajukan, maka penelitian ini menggunakan metode analisis sebagai berikut: (1) Analisis Deskriptif yaitu analisis yang dilakukan untuk menilai karakteristik dari sebuah data, dan dimaksudkan untuk menggambarkan kondisi kinerja yang ada kaitannya dengan kompetensi, motivasi dan lingkungan kerja pustakawan Pengadilan Agama di Sulawesi Selatan/Barat. (2) Analisis Regresi Berganda, suatu analisis sejauh mana pengaruh kompetensi, motivasi dan lingkungan kerja terhadap kinerja pustakawan Pengadilan Agama di Sulawesi Selatan Barat. Adapun prosedur analisis data dalam penelitian menggunakan analisis regresi linear berganda dengan menggunakan uji statistik baik uji F maupun uji t dengan formulasi sebagai berikut: 


\section{$\mathrm{Y}=\mathrm{bo}+\mathrm{b} 1 \mathrm{X} 1+\mathrm{b} 2 \mathrm{X} 2+\mathrm{b} 3 \mathrm{X} 3+\mathrm{ei}$}

Dimana:
$\mathrm{Y}=$ Kinerja pustakawan
$\mathrm{X} 1$ = Kompetensi
$\mathrm{X} 2$ = Motivasi
X3 = Lingkungan Kerja
bo $=$ Konstanta
$\mathrm{b} 1, \mathrm{~b} 2=$ Kofisien Regresi
e = Tingkat kesalahan

Pengolahan hasil dari metode analisis penelitian ini menggunakan komputer dengan memanfaatkan SPSS versi 22 yang dapat memberikan hasil yang cepat dan akurat. Hasil perhitungan dari model analisis tersebut dapat digunakan sebagai dasar dalam menganalisis untuk membuktikan hipotesis-hipotesis yang diajukan. Untuk memperoleh taksiran model regresi, maka nilai $\beta 0, \beta 1, \beta 2$ dihitung dengan menggunakan paket program komputer SPSS (Statistical Package for Social Science). (1) Uji F (Fisher), menurut Sujana (1997:24) adalah untuk menguji apakah variabel X1, hingga X3 secara bersama berpengaruh terhadap Y. uji simultan dilakukan dengan membandingkan nilai F rasio dengan $\mathrm{F}$ tabel. Jika $\mathrm{F}$ rasio lebih besar dari $\mathrm{F}$ tabel maka disimpulkan bahwa variabel dependen $(\mathrm{Y})$ secara bersama dapat mempengaruhi variabel independent (X). (2) Uji T (Student), menurut Al Gifari (1997:2) adalah untuk membuat kesimpulan (inference) mengenai pengaruh masing-masing variabel independent $(\mathrm{X})$ terhadap variabel dependent $(\mathrm{Y})$. Uji parsial dilakukan dengan membandingkan nilai $t$ hitung dengan $t$ tabel. Jika $t$ hitung lebih kecil dari $t$ tabel, artinya variabel independent $(X)$ tidak berpengaruh terhadap nilai variabel dependen $(\mathrm{Y})$ begitu jika terjadi sebaliknya.

\section{Pembahasan}

\section{A. Karakteristik Responden}

Karakteristik responden merupakan data pendukung yang ada pada bagian awal kuesioner. Pada bagian tersebut, responden di data berdasarkan jenis kelamin, usia, jenjang Pendidikan terakhir dan masa kerja. Berikut hasil pendataan data responden dalam bentuk tabel di bawah ini :

1. Jenis Kelamin

Table 3. Responden Berdasarkan Jenis Kelamin

\begin{tabular}{|c|c|c|c|}
\hline No & Jenis Kelamin & Frekuensi & $\%$ \\
\hline 1 & Laki-laki & 26 & 46,43 \\
\hline 2 & Perempuan & 30 & 53,57 \\
\hline & Total & 56 & $\mathbf{1 0 0}$ \\
\hline
\end{tabular}

Sumber : data diolah, Tahun 2021.

Berdasarkan tabel 3 di atas menunjukan bahwa responden yang berjenis laki-laki ada 26 orang atau $46,43 \%$ sedangkan yang berjenis kelamin perempuan ada 30 orang atau $53,57 \%$.

2. Usia

Tabel 4. Responden Berdasarkan Usia

\begin{tabular}{|c|c|c|c|}
\hline No & Usia & Jumlah Responden & $\%$ \\
\hline 1 & $26-30$ Tahun & $\mathbf{1 0}$ & $\mathbf{1 7 , 4}$ \\
\hline 2 & $31-35$ Tahun & $\mathbf{2 0}$ & $\mathbf{3 5 , 7}$ \\
\hline 3 & $36-40$ Tahun & $\mathbf{8}$ & $\mathbf{1 4 , 2 8}$ \\
\hline 4 & $41-45$ Tahun & $\mathbf{1 1}$ & $\mathbf{2 0 , 6}$ \\
\hline 5 & $46-50$ Tahun & $\mathbf{3}$ & $\mathbf{4 , 7 6}$ \\
\hline 6 & $51-55$ Tahun & $\mathbf{3}$ & $\mathbf{4 , 7 6}$ \\
\hline 7 & $>55$ Tahun & $\mathbf{1}$ & $\mathbf{2 , 5}$ \\
\hline & Total & $\mathbf{5 6}$ & $\mathbf{1 0 0}$ \\
\hline
\end{tabular}

Sumber : data diolah, Tahun 2021.

Berdasarkan tabel 4 menunjukkan bahwa penyebaran usia menggunakan skala 5 karena bervariasinya umur responden dan sebagian besar umur responden berada pada skala tersebut. Jumlah 
usia pegawai yang paling banyak adalah yang berusia 31 - 35 tahun dengan jumlah 20 orang atau $35,7 \%$, kemudian usia terbanyak kedua antara $41-45$ tahun sebanyak 11 orang atau $20,6 \%$, yang berusia 26-30 tahun sebanyak 10 Orang atau 17,4\%, kemudian kelompok yang lain menyebar. Secara keseluruhan yang memiliki jumlah usia relative paling kecil pada kelompok 55 tahun.

3. Tingkat Pendidikan

Data tentang jumlah responden berdasarkan tingkat Pendidikan dapat dilihat pada tabel 5 berikut ini :

Tabel 5. Responden Berdasarkan Tingkat Pendidikan

\begin{tabular}{|c|c|c|c|}
\hline No & Tingkat Pendidikan & Jumlah Responden & $\%$ \\
\hline 1 & SMA & $\mathbf{0}$ & $\mathbf{0}$ \\
\hline 2 & Diploma & $\mathbf{2 0}$ & 35,72 \\
\hline 3 & S1 & $\mathbf{3 0}$ & $\mathbf{5 3 , 5 7}$ \\
\hline 4 & S2 & $\mathbf{6 6}$ & $\mathbf{1 0 , 7 1}$ \\
\hline & Total & $\mathbf{1 0 0}$ \\
\hline
\end{tabular}

Sumber data diolah, Tahun 2021.

Berdasarkan tabel 5 menunjukkan bahwa jumlah responden berdasarkan Pendidikan lebih banyak yang sudah menempuh jenjang S1 yaitu 30 orang atau 53,57\%, untuk jenjang sarjana strata 2 sebanyak 6 orang atau 10,71 \% dan responden yang jenjang diploma sebanyak 20 orang atau 35,72\%.

\section{Masa Karja}

Data tentang jumlah responden berdasarkan masa kerja dapat dilihat pada tabel 6 berikut ini :

Tabel 6. Responden Berdasarkan Masa Kerja

\begin{tabular}{|c|c|c|c|}
\hline No & Masa Kerja & Jumlah Responden & $\%$ \\
\hline 1 & $1-5$ Tahun & $\mathbf{5}$ & $\mathbf{8 , 9 2}$ \\
\hline 2 & $6-10$ Tahun & $\mathbf{1 5}$ & $\mathbf{2 6 , 7 8}$ \\
\hline 3 & $11-20$ Tahun & $\mathbf{2 0}$ & $\mathbf{3 5 , 7 2}$ \\
\hline 4 & $>20$ Tahun & $\mathbf{1 6}$ & $\mathbf{2 8 , 5 8}$ \\
\hline & Total & $\mathbf{5 6}$ & $\mathbf{1 0 0}$ \\
\hline
\end{tabular}

Sumber data diolah, Tahun 2021.

Berdasarkan data tabel 6 diatas menunjukkan bahwa distribusi masa kerja responden menjadi pustakawan di Pengadilan Agama yang paling banyak sudah bekerja selama 11-20 tahun. Jumlah pustakawan yang sudah bekerja selama 11 - 20 tahun ada 20 orang atau 35,72\% disusul jumlah pustakawan dengan masa kerja selama 6 - 10 tahun 15 orang atau 26,78\%. Jumlah pustakawan dengan masa kerja lebih dari 20 tahun ada 16 orang atau $28,58 \%$.

\section{B. Deskripsi Variabel Penelitian}

Setelah melakukan penelitian, telah diperoleh data primer dan data sekunder yang diperlukan sebagai informasi yang akurat. Selanjutnya data yang telah terkumpul tersebut dilakukan deskripsi penelitian yang bertujuan untuk memberikan penjelasan mengenai hasil jawaban dari masing-masing responden atas pernyataan yang diajukan dengan variabel independent yang terdiri dari variabel kompetensi (X1), motivasi (X2) dan lingkungan kerja (X3). Variabel dependen dalam penelitian ini adalah variabel kinerja pustakawan $(\mathrm{Y})$.

1. Variabel Kompetensi

Kompetensi merupakan kemampuan melaksanakan pekerjaan atau tugas yang didasari keterampilan maupun pengetahuan dan didukung oleh sikap kerja yang ditetapkan oleh pekerjaan. Kompetensi menunjukkan pengetahuan, keterampilan maupun pendidikan dan didukung oleh sikap kerja yang ditetapkan oleh pekerjaan. Kompetensi menunjukkan pengetahuan, keterampilan dan sikap tertentu dari suatu profesi dalam ciri keahlian tertentu, yang menjadi ciri dari seorang profesional. Keprofesionalan dari seorang pustakawan membawa nilai positif bagi pustakawan. Indikator variabel 
ini adalah : (a) pengalaman kerja, (b) Pendidikan, (c) pengetahuan dan (d) keterampilan. Gambaran tentang variabel kompetensi, dirinci menurut indikator dapat dilihat pada Tabel 7.

Tabel 7. Deskripsi Variabel Kompetensi

\begin{tabular}{|c|c|c|c|c|c|c|}
\hline \multirow{2}{*}{ Indikator } & \multicolumn{5}{|c|}{ Frekuensi Distribusi Jawaban } & \multirow{2}{*}{ Rata-Rata Skor } \\
\hline & 1 & 2 & 3 & 4 & 5 & \\
\hline $\begin{array}{l}\text { Pengalaman } \\
\text { Kerja }\end{array}$ & $0(0 \%)$ & $2(3,57 \%)$ & $7(12,5)$ & $34(60,7)$ & $13(23,2)$ & 4,00 \\
\hline Pendidikan & $0(0 \%)$ & $1(1,79 \%)$ & $6(10,7)$ & $35(62,5)$ & $14(25 \%)$ & 3,91 \\
\hline Pengetahuan & $0(0 \%)$ & $0(0 \%)$ & $6(10.7 \%)$ & $24(42,8 \%)$ & $26(46,4)$ & 4,23 \\
\hline Keterampilan & $0(0 \%)$ & $2(3,57 \%)$ & $10(17,9)$ & $29(51,8)$ & $15(26,7 \%)$ & 4,11 \\
\hline
\end{tabular}

Sumber : data diolah, tahun 2021

Berdasarkan data Tabel 7 terlihat bahwa rata-rata skor indikator dari 56 responden, yang terbesar adalah indikator pengetahuan yaitu sebesar 4,23. Indikator ini memiliki konstribusi terbesar dalam variabel kompetensi, maka dapat disimpulkan bahwa secara rata-rata responden yang dijadikan sampel penelitian memiliki kompetensi yang sangat baik karena berorientasi pada pengetahuan.

2. Variabel Motivasi

Motivasi merupakan hasil sejumlah proses yang bersifat internal atau eksternal bagi seorang individu, yang menyebabkan timbulnya sikap entutiasme dan persistensi dalam hal melaksanakan kegiatan. Seberapa kuat motivasi yang dimiliiki individu akan banyak menentukan terhadap kualitas perilaku yang ditampilkannya baik dalam konteks belajar, bekerja maupun dalam kehidupan lainnya. Indikator variabel ini adalah (a) fisiologis/kebutuhan diri, (b) keamanan, (c) social, (d) penghargaan dan (e) aktualisasi diri. Gambaran tentang variabel gaya kepemimpinan, dirinci menurut indikatornya dapat dilihat pada tabel 8 berikut :

Tabel 8. Deskripsi Variabel Motivasi

\begin{tabular}{|c|c|c|c|c|c|c|}
\hline \multirow{2}{*}{ Indikator } & \multicolumn{5}{|c|}{ Frekuensi Distribusi Jawaban } & \multirow{2}{*}{ Rata-Rata Skor } \\
\hline & 1 & 2 & 3 & 4 & 5 & \\
\hline Fisiologis & - & - & $8(14,28 \%)$ & $38(67,85 \%)$ & $10(17,85 \%)$ & 4,08 \\
\hline Keamanan & - & $4(7,14 \%)$ & $5(8,92 \%)$ & $42(75 \%)$ & $5(8,92 \%)$ & 3,96 \\
\hline Sosial & - & $4(7,14 \%)$ & $2(3,57 \%)$ & $42(75 \%)$ & $8(14,28 \%)$ & 4,23 \\
\hline Penghargaan & - & - & $8(14,28 \%)$ & $33(58,92 \%)$ & $15(26,78 \%)$ & 4,08 \\
\hline Aktualitas Diri & $4(7,14 \%)$ & $1(1,78 \%)$ & $10(17,85 \%)$ & $30(53,57 \%)$ & $11(19,64 \%)$ & 3,96 \\
\hline
\end{tabular}

Sumber : data diolah, Tahun 2021.

Berdasarkan data Tabel 8 terlihat bahwa rata-rata skor indikator dari 56 responden, yang terbesar adalah indikator sosial yaitu sebesar 4,23 dengan indikator motivasi sosial, indikator ini memiliki kontribusi terbesar dalam variabel motivasi, maka dapat disimpulkan bahwa secara rata-rata responden yang dijadikan sampel penelitian memiliki motivasi yang sangat baik karena berorientasi pada kebutuhan social.

\section{Variabel Lingkungan Kerja}

Lingkungan kerja adalah keseluruhan sarana dan prasarana yang ada di sekitar karyawan yang sedang melakukan pekerjaan itu sendiri. Lingkungan kerja ini meliputi tempat kerja, fasilitas dan alat bantu kerja, kebersihan, pencahayaan dan ketenangan. Indikator variabel ini adalah : (a) suhu udara dan sirkulasi, (b) penerangan/pencahayaan, (c) ukuran ruang perpustakaan, (d) tata ruang perpustakaan, (e) kebersihan dan suara bising, (f) penggunaan warna dan peralatan kantor, (g) keamanan kerja, (h) Hubungan kerja antara atasan dengan bawahan. Gambaran tentang variabel kinerja pustakawan, dirinci menurut indikatornya dapat dilihat pada Tabel 9. 
Tabel 9. Deskripsi Variabel Lingkungan Kerja

\begin{tabular}{|c|c|c|c|c|c|c|}
\hline \multirow{2}{*}{ Indikator } & \multicolumn{5}{|c|}{ Frekuensi Distribusi Jawaban } & \multirow{2}{*}{ Rata-Rata Skor } \\
\hline & 1 & 2 & 3 & 4 & 5 & \\
\hline Fisiologis & - & - & $8(14,28 \%)$ & $38(67,85 \%)$ & $10(17,85 \%)$ & 4,08 \\
\hline Keamanan & - & $4(7,14 \%)$ & $5(8,92 \%)$ & $42(75 \%)$ & $5(8,92 \%)$ & 3,96 \\
\hline Sosial & - & $4(7,14 \%)$ & $2(3,57 \%)$ & $42(75 \%)$ & $8(14,28 \%)$ & 4,23 \\
\hline Penghargaan & - & - & $8(14,28 \%)$ & $33(58,92 \%)$ & $15(26,78 \%)$ & 4,08 \\
\hline Aktualitas Diri & $4(7,14 \%)$ & $1(1,78 \%)$ & $10(17,85 \%)$ & $30(53,57 \%)$ & $11(19,64 \%)$ & 3,96 \\
\hline
\end{tabular}

Sumber : Diolah dari data primer, Tahun 2021

Berdasarkan data Tabel 9 terlihat bahwa rata-rata skor indikator dari 56 responden, yang terbesar adalah indikator kebersihan dan suara bising yaitu sebesar 4,15 dengan indikator hubungan kerja antara atasan dan bawahan sebesar 4,15, Indikator ini memiliki kontribusi terbesar dalam variabel lingkungan kerja. dapat disimpulkan bahwa secara rata-rata responden yang dijadikan sampel penelitian memiliki lingkungan kerja yang baik karena berorientasi pada kebersihan dan suara bisih serta hubungan kerja antara atasan dan bawahan.

4. Variabel Kinerja Pegawai

Kinerja adalah hasil kerja yang dicapai oleh karyawan dalam suatu organisasi sesuai dengan wewenang dan tanggung jawab yang diberikan organisasi dalam upaya mencapai misi, visi dan tujuan organisasi. Indikator variabel ini adalah : (a) orientasi pelayanan, (b) integritas, (c) komitmen, (d) disiplin, (e) kerjasama dan (f) kepemimpinan. Gambaran tentang variabel kinerja pegawai, dirinci menurut indikatornya dapat di lihat pada Tabel 10 sebagai berikut :

Tabel 10. Deskripsi Variabel Kinerja pustakawan

\begin{tabular}{|c|c|c|c|c|c|c|}
\hline \multirow[b]{2}{*}{ Indikator } & \multicolumn{5}{|c|}{ Frekuensi Distribusi Jawaban } & \multirow{2}{*}{$\begin{array}{l}\text { Rata- } \\
\text { Rata } \\
\text { Skor }\end{array}$} \\
\hline & 1 & 2 & 3 & 4 & 5 & \\
\hline Orientasi pelayanan & - & $1(1,78 \%)$ & $5(8,92 \%)$ & $36(7,14 \%)$ & $14(25 \%)$ & 4,01 \\
\hline Integritas & - & - & $6(10.71 \%)$ & $36(64,28 \%)$ & $14(25 \%)$ & 4,05 \\
\hline Komitmen & $1(1,78 \%)$ & $1(1,78 \%)$ & $4(7,14 \%)$ & $33(58,92 \%)$ & $17(30,35 \%)$ & 4,12 \\
\hline Disiplin & - & $1(1,78 \%)$ & $4(7,14 \%)$ & $43(76,78 \%)$ & $8(14,28 \%)$ & 4,05 \\
\hline Kerjasama & $2(3,57 \%)$ & - & $6(10,71 \%)$ & $38(67,85 \%)$ & $10(17,85 \%)$ & 4,03 \\
\hline Kepemimpinan & - & $1(1,78 \%)$ & $4(7,14 \%)$ & $38(67,85 \%)$ & $13(23,21 \%)$ & 4,08 \\
\hline
\end{tabular}

Sumber: data diolah, tahun 2021

Berdasarkan data Tabel 10 terlihat bahwa rata-rata skor indikator dari 56 responden, yang terbesar adalah indikator komitmen yaitu sebesar 4,12 indikator ini memiliki kontribusi terbesar dalam variabel kinerja pustakawan, maka dapat disimpulkan bahwa secara rata-rata responden yang dijadikan sampel penelitian memiliki kinerja yang baik karena berorientasi pada komitmen yang baik.

\section{Uji Instrumen Penelitian}

1. Uji Validitas

Analisis faktor dilakukan dengan cara mengkorelasikan jumlah skor faktor dengan skor total. Bila korelasi tiap faktor tersebut positif dan besarnya 0,3 ke atas maka faktor tersebut merupakan contruct yang kuat. Jadi berdasarkan analisis faktor itu dapat disimpulkan bahwa instrument tersebut memiliki validitas konstruksi yang baik. Hasil uji validitas ditunjukkan pada tabel 11 sebagai berikut :

Tabel 11. Hasil Uji Validitas

\begin{tabular}{|c|c|c|c|}
\hline Instrumen & r hitung & r kritis & Ket \\
\hline Kompetensi (X1) & & & \\
\hline 1. Pengalaman Kerja & & & Valid \\
\hline$-\quad$ Pertanyaan 1 & 0,67 & 0,30 & Valid \\
\hline$-\quad$ Pertanyaan 2 & 0,71 & 0,30 & Valid \\
\hline
\end{tabular}




\begin{tabular}{|c|c|c|c|}
\hline Instrumen & r hitung & r kritis & Ket \\
\hline \multicolumn{4}{|l|}{ 2. Pendidikan } \\
\hline - $\quad$ Pertanyaan 1 & 0,77 & & \\
\hline Pertanyaan 2 & 0,85 & 0,30 & Valid \\
\hline Pertanyaan 3 & 0,77 & 0,30 & Valid \\
\hline Pertanyaan 4 & 0,95 & 0,30 & Valid \\
\hline \multicolumn{4}{|l|}{ 3. Pengetahuan } \\
\hline - $\quad$ Pertanyaan 1 & 0,91 & 0,30 & Valid \\
\hline Pertanyaan 2 & 0,90 & 0,30 & Valid \\
\hline $\begin{array}{ll}- & \text { Pertanyaan } 3 \\
\end{array}$ & 0,63 & 0,30 & Valid \\
\hline Pertanyaan 4 & 0,71 & 0,30 & Valid \\
\hline 4. $\quad$ Keterampilan & & 0,30 & Valid \\
\hline - $\quad$ Pertanyaan 1 & 0,74 & 0,30 & Valid \\
\hline $\begin{array}{ll}- & \text { Pertanyaan } 2 \\
\end{array}$ & 0,72 & 0,30 & Valid \\
\hline $\begin{array}{ll}- & \text { Pertanyaan } 3 \\
\end{array}$ & 0,79 & 0,30 & Valid \\
\hline Pertanyaan 4 & 0,85 & 0,30 & Valid \\
\hline Pertanyaan 5 & 0,86 & 0,30 & Valid \\
\hline \multicolumn{4}{|l|}{ Motivasi (X2) } \\
\hline \multicolumn{4}{|c|}{$\begin{array}{l}\text { 1. Fisiologi/Kebutuhan } \\
\text { Fisik }\end{array}$} \\
\hline - $\quad$ Pertanyaan 1 & 0,68 & 0,30 & Valid \\
\hline $\begin{array}{ll}- & \text { Pertanyaan } 2 \\
\end{array}$ & 0,72 & 0,30 & Valid \\
\hline - $\quad$ Pertanyaan 3 & 0,61 & 0,30 & Valid \\
\hline \multicolumn{4}{|l|}{ 2. $\quad$ Keamanan } \\
\hline $\begin{array}{ll} & \text { Pertanyaan } 1\end{array}$ & 0,58 & 0,30 & Valid \\
\hline $\begin{array}{ll}- & \text { Pertanyaan } 2 \\
\end{array}$ & 0,80 & 0,30 & Valid \\
\hline - $\quad$ Pertanyaan 3 & 0,74 & 0,30 & Valid \\
\hline \multicolumn{4}{|l|}{ 3. Sosial } \\
\hline - $\quad$ Pertanyaan 1 & 0,64 & 0,30 & Valid \\
\hline $\begin{array}{ll}- & \text { Pertanyaan } 2 \\
\end{array}$ & 0,64 & 0,30 & Valid \\
\hline - $\quad$ Pertanyaan 3 & 0,82 & 0,30 & Valid \\
\hline \multicolumn{4}{|l|}{ 4. $\quad$ Penghargaan } \\
\hline - Pertanyaan 1 & 0,84 & 0,30 & Valid \\
\hline $\begin{array}{ll}- & \text { Pertanyaan } 2 \\
\end{array}$ & 0,68 & 0,30 & Valid \\
\hline Pertanyaan 3 & 0,74 & 0,30 & Valid \\
\hline - $\quad$ Pertanyaan 4 & 0,64 & 0,30 & Valid \\
\hline \multicolumn{4}{|l|}{ 5. $\quad$ Aktualisasi diri } \\
\hline - Pertanyaan 1 & 0,64 & 0,30 & Valid \\
\hline $\begin{array}{ll}- & \text { Pertanyaan } 2 \\
\end{array}$ & 0,82 & 0,30 & Valid \\
\hline - $\quad$ Pertanyaan 3 & 0,84 & 0,30 & Valid \\
\hline \multicolumn{4}{|l|}{ Lingkungan Kerja (X3) } \\
\hline \multicolumn{4}{|l|}{$\begin{array}{l}\text { 1. Suhu dan sirkulasi } \\
\text { Udara }\end{array}$} \\
\hline - Pertanyaan 1 & 0,82 & 0,30 & Valid \\
\hline - $\quad$ Pertanyaan 2 & 0,85 & 0,30 & Valid \\
\hline \multicolumn{4}{|c|}{ 2. Penerangan/pencahayaan } \\
\hline - $\quad$ Pertanyaan 1 & 0,69 & 0,30 & Valid \\
\hline $\begin{array}{ll} & \text { Pertanyaan } 2 \\
\end{array}$ & 0,63 & 0,30 & Valid \\
\hline \multicolumn{4}{|c|}{ 3. Ukuran ruang perpustakaan } \\
\hline - Pertanyaan 1 & 0,69 & 0,30 & Valid \\
\hline $\begin{array}{ll} & \text { Pertanyaan } 2 \\
\end{array}$ & 0,75 & 0,30 & Valid \\
\hline \multicolumn{4}{|l|}{$\begin{array}{ll}\text { 1. } & \text { Tata letak ruang } \\
\text { perpustakaan }\end{array}$} \\
\hline - Pertanyaan 1 & 0,71 & 0,30 & Valid \\
\hline - $\quad$ Pertanyaan 2 & 0,63 & 0,30 & Valid \\
\hline \multicolumn{4}{|c|}{ 5. Kebersihan \& suara bising } \\
\hline - $\quad$ Pertanyaan 1 & 0,74 & 0,30 & Valid \\
\hline $\begin{array}{ll}- & \text { Pertanyaan } 2 \\
\end{array}$ & 0,77 & 0,30 & Valid \\
\hline - Pertanyaan 3 & 0,78 & 0,30 & Valid \\
\hline
\end{tabular}




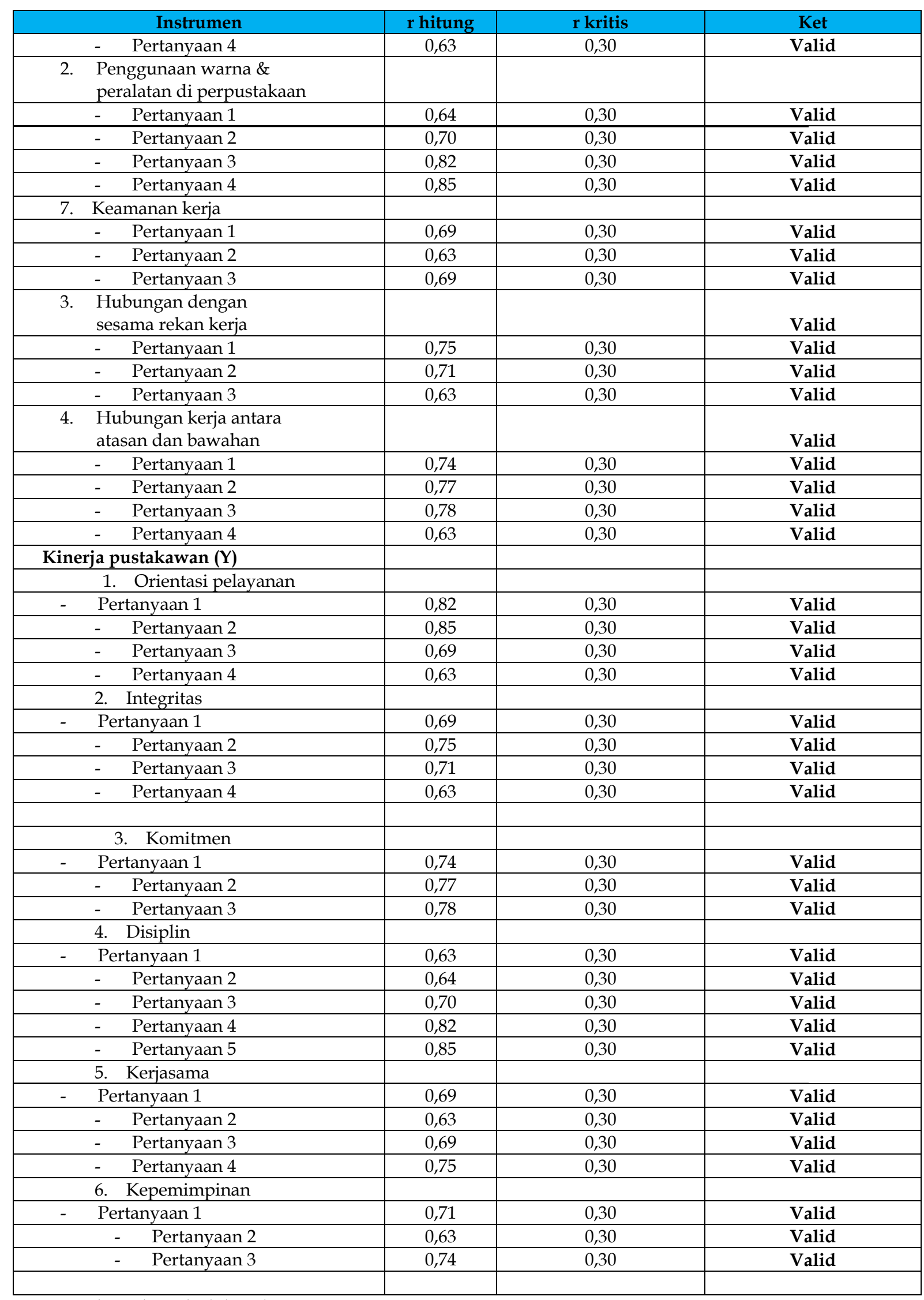

Sumber: data diolah, tahun 2021 
Berdasarkan tabel 11 di atas dapat diketahui, bahwa semua butir dalam instrument adalah valid karena koefisien korelasi semua instrument pertanyaan/faktor tersebut di atas 0,30. Dengan demikian dapat disimpulkan bahwa seluruh butir pernyataan dinyatakan valid.

\section{Uji Realibilitas}

Teknik yang digunakan untuk menilai reliabilitas adalah Cronbach Alpha dan suatu instrument penelitian dikatakan reliabel (andal), jika alpha lebih besar dari 0,60. Hasil pengujian reliabilitas ditunjukkan pada tabel 12.

Tabel 12. Hasil Uji Reliabilitas

\begin{tabular}{|l|c|c|c|}
\hline \multicolumn{1}{|c|}{ Variabel } & Cronbach's Alpha & Nilai $\mathrm{k}$ & Keterangan \\
\hline Kinerjapustakawan $(\mathrm{Y})$ & 0,934 & 0,60 & Reliabel \\
\hline Kompetensi $\left(\mathrm{X}_{1}\right)$ & 0,887 & 0,60 & Reliabel \\
\hline Motivasi $\left(\mathrm{X}_{2}\right)$ & 0,940 & 0,60 & Reliabel \\
\hline Lingkungan kerja $\left(\mathrm{X}_{3}\right)$ & 0,947 & 0,60 & Reliabel \\
\hline
\end{tabular}

Sumber: data diolah, tahun 2021

Berdasarkan ringkasan hasil uji reliabilitas seperti yang terangkum dalam tabel 12 dapat diketahui bahwa nilai koefisien Cronbach alpha secara keseluruhan nilainya diatas 0,60 (nilai hitung >0,60), sehingga butir-butir pernyataan dalam kuesioner variabel penelitian dapat digunakan untuk melakukan penelitian selanjutnya.

\section{Hasil Penelitian}

1. Uji Normalitas

Uji normalitas bertujuan untuk menguji apakah dalam model regresi variabel terikat dan variabel bebas keduanya mempunyai distribusi normal atau tidak. Model regresi yang baik adalah memiliki distribusi data normal atau ,mendekati normal(Ghozali, 2001: 74). Uji normalitas dalam penelitian dilakukan pada variabel bebas yaitu variabel kompetensi (X1), variabel motivasi(X2), dan variabel lingkungan kerja $(\mathrm{X} 3)$ dengan variabel terikat yaitu variabel kinerja $(\mathrm{Y})$. Pengujian uji normalitas dilakukan dengan uji Kolmogorov-smirnovs (KS), karena data yang diuji lebih dari 50. Dasar pengambilan keputusan adalah jika nilai signifikan $>0,05$, maka model regresi memenuhi asumsi normalitas, jika nilai signifikansi $<0,05$ maka model regresi tidak memenuhi asumsi normalitas. Berikut ini adalah tabel hasil uji normalitas :

Tabel 13. Hasil Uji Normalitas

\begin{tabular}{|l|l|r|}
\hline \multicolumn{2}{|c|}{} & \multicolumn{2}{|c|}{ Unstandardized Predicted Value } \\
\hline \multirow{2}{*}{$\begin{array}{l}\text { Normal } \\
\text { Parametersa,b }\end{array}$} & Mean & 56 \\
\cline { 2 - 3 } $\begin{array}{l}\text { Most Extreme } \\
\text { Differences }\end{array}$ & Std. Deviation & 3.9553571 \\
\cline { 2 - 3 } & Pbsolute & .40189006 \\
\cline { 2 - 3 } & Negitive & .176 \\
\hline \multicolumn{2}{|l|}{ Test Statistic } & .075 \\
\hline Asymp. Sig. (2-tailed) & -.176 \\
\hline
\end{tabular}

Berdasarkan hasil uji normalitas pada tabel 13 dengan menggunakan SPSS 22 di atas, terlihat bahwa nila Asymp.sig. (2-tailed) > 0,05 $(0,159>0,05)$. Berdasarkan hasil tersebut maka dapat disimpulkan bahwa model regresi telah memenuhi asumsi normalitas.

\section{a. Uji Heteroskedasitas}

Uji heterokedastisitas dalam penelitian ini dimaksudkan untuk melihat apakah pengambilan sampel dilakukan dengan benar pada populasi yang tepat atau dengan perkataan lain apakah terjadi ketidaksamaan varians dari residual regresi. Suatu model regresi yang mengandung heterokedastisitas akan menghasilkan parameter yang bisa yang akan menyebabkan kesalahan dalam perlakuan. Suatu model regresi yang baik apabila di dalamnya tidak diperoleh heterokedastisitas melainkan homokedastisitas. 
Uji heterokedastisitas dapat diketahui dengan nilai residualnya. Heterokedastisitas akan muncul apabila terdapat pola tertentu antar keduanya seperti bergelombang dan kontinyu atau menyempit atau melebar teratur, sedangkan homokedastisitas akan muncul apabila tidak diperoleh pola yang jelas atau titik-titik yang diperoleh menyebar di atas dan di bawah angka 0 pada sumbu Y. Adapun hasil uji heterokedastisitas penelitian ini, dapat dilihat pada gambar.

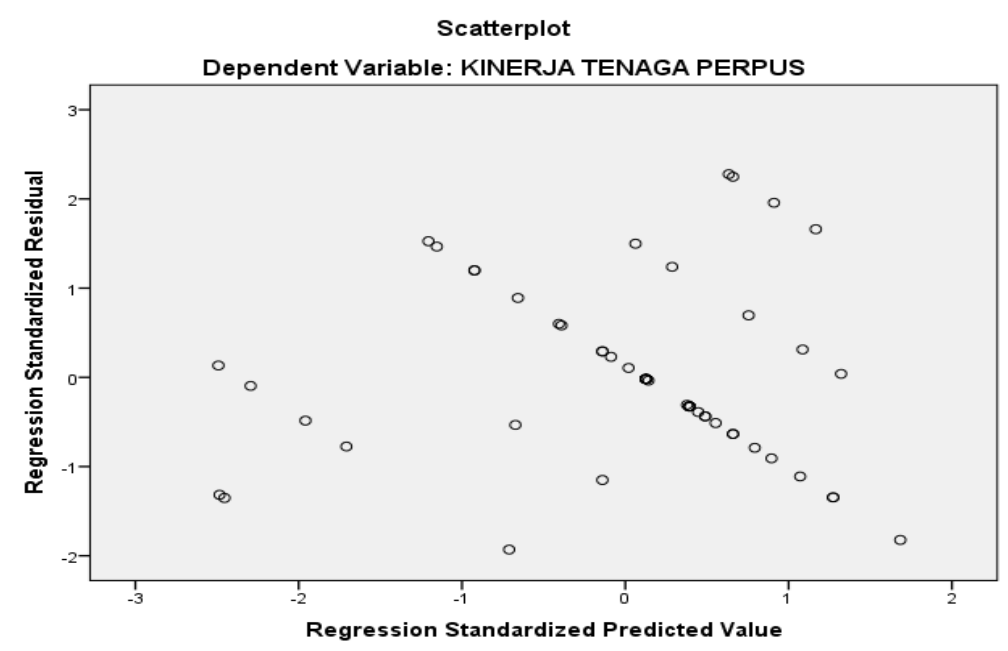

Berdasarkan hasil pengujian asumsi klasik dalam hal ini uji heterokedastisitas menunjukkan bahwa titik-titik menyebar di atas dan di bawah garis nol secara acak. Hal ini berarti model regresi yang digunakan dalam penelitian ini tidak menunjukkan adanya heterokedastisitas, melainkan homokedastisitas, dimana penelitian ini tidak menghasilkan parameter biasa yang menyebabkan kesalahan dalam perlakuan.

\section{b. Uji Multikolinieritas}

Keberadaan multikolinearitas dalam suatu regresi akan mengganggu hasil regresi penelitian, sehingga tidak menghasilkan parameter yang efisien dan efektif yang akan membuat kesalahan dalam parameter yang dihasilkan. Regresi dikatakan baik jika suatu regresi tidak memiliki multikolinearitas di dalamnya sehingga tidak ada gangguan yang diharapkan akan terjadi pada regresi tersebut.

\section{Tabel 14. Hasil Uji Multikolinieritas}

\begin{tabular}{|l|l|l|}
\hline \multirow{2}{*}{ Model } & \multicolumn{2}{|l|}{ Collinearity Statistics } \\
\cline { 2 - 3 } & Tolerance & VIF \\
\hline Kompetensi $\left(\mathrm{x}_{1}\right)$ & 0.675 & 1.481 \\
Motivasi $\left(\mathrm{X}_{2}\right)$ & 0703 & 1.423 \\
Lingkungan kerja $\left(\mathrm{X}_{3}\right)$ & 0.883 & 1.132 \\
\hline
\end{tabular}

Hasil uji multikolinearitas pada tabel 14 menunjukkan bahwa kepemimpinan, lingkungan kerja dan motivasi memiliki nilai VIF yang lebih kecil dari 10 dan nilai toleransinya lebih besar dari 0.1. Ini menunjukkan bahwa indikasi keberadaan multikolinearitas pada persamaan yang dilakukan dalam penelitian ini tidak terbukti atau tidak terdapat multikolinearitas dalam persamaan yang dilakukan atau hubungan yang terjadi antar variabel bebas dapat ditoleransi sehingga tidak akan mengganggu hasil regresi

\section{Pengujian Hipotesis}

Berdasarkan hasil uji asumsi klasik yang meliputi uji normalitas, uji multikolinearitas, dan uji heterokedastisitas menunjukkan bahwa regresi berganda yang diestimasi telah memenuhi syarat asumsi-asumsi klasik sehingga diharapkan hasilnya akan baik dalam menganalisis pengaruh variabel kompetensi, motivasi dan lingkungan kerja terhadap kinerja pustakawan Pengadilan Agama di Sulawesi Selatan/Barat. 
Pengujian terhadap hasil regresi yang diperoleh dilakukan pengujian secara serempak dengan menggunakan uji-F dan pengujian secara parsial dengan menggunakan uji-t untuk lebih jelasnya akan diuraikan sebagai berikut:

\section{a. Pengujian Hipotesis Secara Simultan}

Pengujian secara simultan bertujuan untuk melihat pengaruh kompetensi, motivasi dan lingkungan kerja terhadap kinerja pustakawan Pengadilan Agama di Sulawesi Selatan/Barat. dengan melihat nilai F hitung. Adapun hasil pengujian secara simultan, dapat dilihat pada tabel 15.

Tabel 15. Pengujian secara Simultan (Uji F)

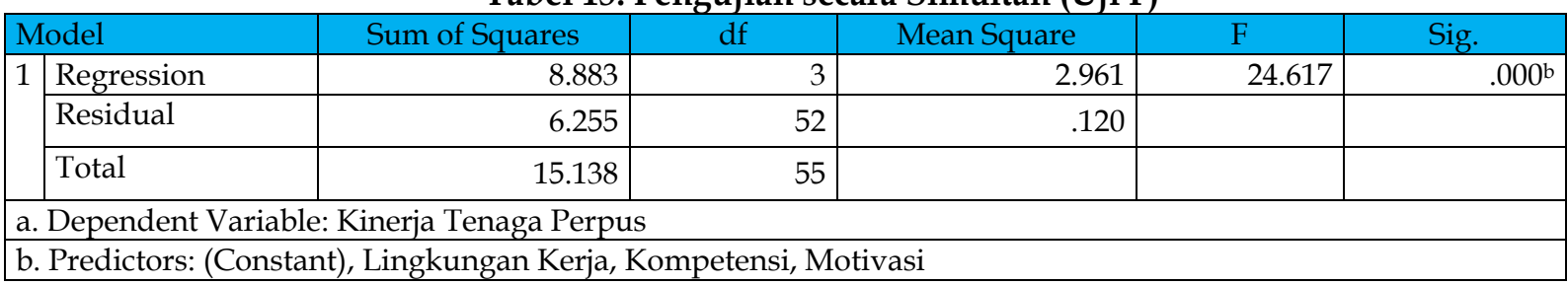

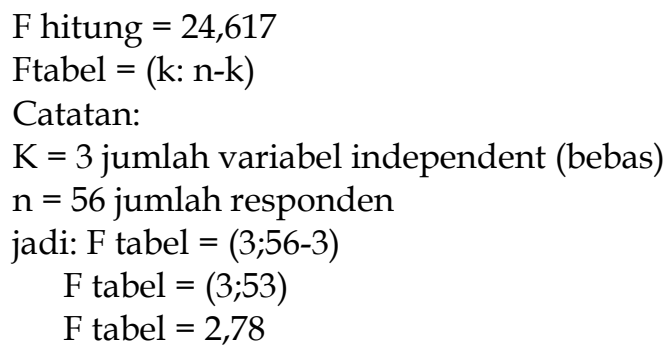

Data pada Tabel 15 menunjukkan bahwa nilai F hitung yang diperoleh adalah 24,617 Sedangkan Ftabel (df1 $=3 ; \mathrm{df2}=52 ; \mathrm{a}=0.05)$ diperoleh dengan tingkat signifikansi 0.000. Dengan demikian, nilai Fhitung $>$ Ftabel atau 24,617 > 2,78 yang berarti berpengaruh signifikansi pada tingkat alpha yang sangat kecil $(0 \%)$. Dengan hasil ini, maka dapat disimpulkan bahwa secara simultan variabel kompetensi, motivasi dan lingkungan kerja berpengaruh positif dan signifikan terhadap kinerja pustakawan Pengadilan Agama di Sulawesi Selatan/Barat. Selanjutnya untuk mengetahui besarnya pengaruh secara simultan kompetensi, motivasi dan lingkungan kerja berpengaruh positif dan signifikan terhadap kinerja pustakawan Pengadilan Agama di Sulawesi Selatan/Barat digunakan koefisien determinasi $\left(\mathrm{R}^{2}\right)$. Perolehan nilai R2 dapat dilihat pada Tabel 16 :

Tabel 16. Hasil Pengujian Koefisien Determinasi $\left(\mathbf{R}^{2}\right)$

\begin{tabular}{|r|rr|r|rr|r|}
\hline Model & R & R Square & Adjusted R Square & Std. Error of the Estimate \\
\hline 1 & $.766^{\mathrm{a}}$ & .587 & .563 & .3471 \\
\hline
\end{tabular}

Berdasarkan hasil pengujian determinasi di atas, dapat dijelaskan bahwa besarnya koefisien determinasi (R2) adalah 0.587. Angka koefisien determinasi ini menyatakan Pengaruh kompetensi, motivasi dan lingkungan kerja adalah sebesar $58.7 \%$, sedangkan sisanya sebesar $41.3 \%$ dipengaruhi oleh variabel lain yang tidak dimasukan dalam penelitian ini.

b. Pengujian Hipotesis secara Parsial

Pengujian hipotesis secara parsial digunakan untuk melihat pengaruh kompetensi, motivasi dan lingkungan kerja terhadap kinerja pustakawan pengadilan agama di Sulawesi selatan/barat. Hasil pengujiannya dapat dilihat melalui nilai $t$ hitung, sedangkan untuk melihat besarnya pengaruh digunakan angka beta atau standardized. Adapun hasil pengujian secara parsial (t-hitung) dapat dilihat pada tabel 17. 
Tabel 17. Pengaruh Kompetensi, Motivasi Kerja dan Lingkungan Kerja Terhadap Kinerja pustakawan Pengadilan Agama di Sulawesi Selatan/Barat

\begin{tabular}{|c|c|c|c|c|c|}
\hline \multirow{2}{*}{ Model } & \multicolumn{2}{|c|}{$\begin{array}{c}\text { Unstandardized } \\
\text { Coefficients }\end{array}$} & \multirow{2}{*}{$\begin{array}{c}\begin{array}{c}\text { Standardized } \\
\text { Coefficients }\end{array} \\
\text { Beta }\end{array}$} & \multirow[t]{2}{*}{$\mathbf{T}$} & \multirow[t]{2}{*}{ Sig. } \\
\hline & B & Std. Error & & & \\
\hline (Constant) & .904 & .509 & & 776 & .082 \\
\hline kompetensi & .403 & .134 & .385 & 3.008 & .004 \\
\hline motivasi & .320 & .120 & .430 & 4.832 & .003 \\
\hline lingkungan kerja & .356 & .180 & .438 & 4.994 & .003 \\
\hline
\end{tabular}

Dasar pengambilan keputusan untuk uji persial(t- hitung):

$\mathrm{H} 0$ diterima dan $\mathrm{H1}$ ditolak jika nilai t hitung $<\mathrm{t}$ table atau nilai signiifikan $>0,05$.

$\mathrm{H} 0$ ditolak dan $\mathrm{H} 1$ diterima jika nilai t hitung $>\mathrm{t}$ tabel atau nilai signifikan $<0,05$

Untuk mencari nilai $\mathrm{t}$ tabel: $\mathrm{t}$ tabel $=($ tingkat kepercayaan dibagi 2 ; jumlah responden - jumlah variabel bebas-1

$$
\begin{aligned}
\mathrm{t} \text {-tabel } & =(\mathrm{a} / 2 ; \mathrm{n}-3-1 \\
& =(0,05 / 2 ; 56-3-1 \\
& =(0,025 ; 52) \\
\mathrm{t} \text {-tabel } & =2,006
\end{aligned}
$$

Berdasarkan pengujian secara parsial terhadap kinerja pustakawan menunjukkan bahwa kompetensi (X1) mempunyai thitung 3.008> ttabel 2.006 dengan tingkat signifikan sebesar $0.004<0.05$ maka dapat disimpulkan bahwa H0 ditolak dan $\mathrm{H} 1$ diterima. ini berarti kompetensi (X1) berpengaruh positif dan signifikan terhadap kinerja pustakawan Pengadilan Agama di Sulawesi Selatan/barat. Sementara motivasi (X2) mempunyai thitung 4.832> ttabel 2.006 dengan tingkat signifikan $0.003<0.05$ maka dapat disimpulkan bahwa H0 ditolak dan H1 diterima ini berarti bahwa motivasi (X2) berpengaruh positif dan signifikan terhadap kinerja pustakawan Pengadilan Agama di Sulawesi Selatan/Barat, Sedangkan lingkungan kerja (X3) mempunyai thitung 4.994> ttabel 2.006 dengan tingkat signifikan sebesar $0.003<0.05$ maka dapat disimpulkan bahwa H0 ditolak dan H1 diterima berarti bahwa lingkungan kerja berpengaruh positif dan signifikan kinerja terhadap kinerja pustakawan Pengadilan Agama di Sulawesi Selatan/Barat. Selanjutnya pada tabel di atas, dapat pula diketahui hasil persamaan regresi linear berganda dari model penelitian ini adalah sebagai berikut:

$$
\begin{gathered}
\mathrm{Y}=\mathrm{b} 0+\mathrm{b} 1 \mathrm{X} 1+\mathrm{b} 2 \mathrm{X} 2+\mathrm{b} 3 \mathrm{X} 3+\mathrm{e} \\
\mathrm{Y}=0.904+0.403 \mathrm{X} 1+0.320 \mathrm{X} 2+0.356 \mathrm{X} 3
\end{gathered}
$$

Berdasarkan persamaan regresi linier berganda tersebut di atas, maka dapat diinterpretasikan sebagai berikut:

a) Nilai koefisien regresi variabel kompetensi ( $\beta 1$ ), adalah 0.403 yang menunjukkan bahwa kompetensi berpengaruh positif dan signifikan terhadap kinerja pustakawan Pengadilan Agama di Sulawesi Selatan/Barat. Koefisien b1 tersebut positif dan signifikan karena nilai sig $=0,004$ lebih kecil dari 0,05 hal tersebut dapat dijelaskan apabila terjadi peningkatan kompetensi sebesar 40,3\% dari variabel lainya konstan, maka akan meningkatkan kompetensi pada kinerja pustakawan Pengadilan Agama di Sulawesi Selatan/Barat.

b) Nilai koefisien regresi variabel motivasi ( $\beta 2$ ) adalah 0.320 menunjukkan bahwa motivasi berpengaruh positif dan signifikan terhadap kinerja pustakawan Pengadilan Agama di Sulawesi Selatan/Barat. koefisien b2 tersebut positif dan signifikan nilai sig $=0.003<0.05$, hal tersebut dapat dijelaskan apabila terjadi peningkatan motivasi sebesar 32.0\% dari variabel lainya konstan, maka akan meningkatkan motivasi pada kinerja pustakawan Pengadilan Agama di Sulawesi Selatan/Barat.

c) Nilai koefisien regresi variabel lingkungan kerja (B3) adalah 0.356 menunjukkan bahwa lingkungan kerja berpengaruh positif dan signiifikan terhadap kinerja pustakawan Pengadilan Agama di Sulawesi Selatan/Barat. koefisien b3 tersebut positif dan signifikan, nila sig $=0.003<$ 0.05 , hal tersebut dapat dijelaskan apabila terjadi peningkatan lingkungan kerja sebesar $35,6 \%$ 
dari variabel lainya konstan, maka akan meningkatkan lingkungan kerja pada kinerja pustakawan Pengadilan Agama di Sulawesi Selatan/Barat.

Berdasarkan uraian di atas dapat diketahui bahwa dari ketiga variabel independen tersebut, maka variabel kompetensi (X1), motivasi (X2) dan lingkungan kerja (X3) berpengaruh terhadap kinerja pustakawan $(\mathrm{Y})$, hal ini dikarenakan nilai koefisien regresi variabel pengaruh kompetensi yaitu 0.403 , motivasi sebesar 0.320 dan lingkungan kerja sebesar 0.356 dan diantara ketiga variabel, lingkungan kerja yang memiliki pengaruh yang paling dominan yaitu sebesar 4.994 .

\section{E. Pembahasan}

Berdasarkan tujuan penelitian ini yakni untuk mengetahui dan menganalisis pengaruh kompetensi, motivasi kerja dan lingkungan kerja terhadap pustakawan Pengadilan Agama di Sulawesi Selatan/Barat. Setelah dilakukan pengujian hipotesis penelitian ini, maka ketiga variabel bebas yakni : kompetensi (X1), motivasi kerja (X2), dan lingkungan kerja (X3) berpengaruh positif dan signifikan terhadap kinerja pustakawan Pengadilan Agama di Sulawesi Selatan/Barat. Sebagaimana diketahui bahwa penelitian ini secara serentak atau bersama-sama ketiga variabel bebas terhadap variabel terikat yang menunjukkan pengaruh positif dan signifikan yang dibuktikan dengan besarnya kontribusi (R2) $=0,587$ atau 58,7 \%. Artinya kinerja pustakawan dapat diprediksikan bahwa untuk meningkatkan kinerja pustakawan perlu menggunakan ketiga variabel bebas tersebut. Sedang adanya sisa hanya 41.3 $\%$ menunjukkan bahwa masih perlu mencari variabel yang belum dapat teridentifikasi dalam penelitian ini, sehingga bagi para peneliti selanjutnya harus menelusuri lebih mendalam sehingga ditemukan variabel yang dapat memperbesar pengaruhnya terhadap kinerja pustakawan Pengadilan Agama di Sulawesi Selatan/Barat. Di samping memperlihatkan temuan secara serentak atau simultan ketiga variabel tersebut, maka secara parsial ketiga variabel bebas juga perlu dibahas terhadap variabel terikatnya. Untuk mengetahui dan menganalisis secara parsial pengaruh tersebut, maka berikut ini akan diuraikan satu persatu :

\section{Pengaruh Kompetensi terhadap Kinerja Pustakawan}

Hasil uji secara parsial dapat diketahui bahwa variabel kompetensi berpengaruh positif dan signifikan terhadap kinerja pustakawan Pengadilan Agama di Sulawesi Selatan/Barat. Hal ini menunjukkan adanya hubungan yang searah antara kompetensi dengan kinerja pustakawan, dalam arti jika peningkatan kompetensi, maka kinerja pustakawan cenderung meningkat. Peningkatan variabel kompetensi sangat ditentukan oleh besarnya peran indikator yang membentuknya yaitu: a. Pengalaman kerja yang terdiri dari: 1) Pengalaman kerja pustakawan mendukung pekerjaan yang menjadi tanggung jawabnya, 2) Pengalaman pustakawan mendukung kreatifitasnya dalam menyelesaikan pekerjaan, 3) Pustakawan mampu memecahkan masalah yang dihadapi berdasarkan pengalaman kerja. b. Pendidikan yang terdiri dari : 1) Latar belakang pendidikan pustakawan berdampak dalam menyelesaikan tugas-tugasnya, 2) Disiplin ilmu yang dimiliki pustakawan berdampak pada pekerjaan yang dikerjakan, 3) Latar belakang pendidikan pustakawan mempunyai peran penting dalam suatu perpustakaan. c. pengetahuan yang terdiri dari : 1) Pustakawan mengetahui pekerjaan yang dikerjakan sesuai dengan wawasan pengetahuan yang dimiliki, 2) Dengan pengetahuan yang pustakawan miliki dapat memecahkan masalah pekerjaan, 3) Dengan pengetahuan yang pustakawan miliki dapat menyelesaikan tugas dengan baik dan tepat waktu, 4) Pustakawan kurang mampu dalam membuat katalog dan klasifikasi yang merupakan pekerjaan teknis di perpustakaan, $\mathrm{d}$. Keterampilan yang terdiri dari : 1) Dengan keterampilan yang pustakawan miliki, membuat memiliki inisiatif dalam bekerja, 2) Dengan keterampilan yang dimiliki, pustakawan dapat menyelesaikan pekerjaan yang menjadi tugas pokoknya, 3 Pustakawan berusaha mencari informasi tentang pelaksanaan tugas-tugas yang terkait dengan tugas pokoknya, 4) pustakawan mempunyai inisiatif untuk belajar tentang perkembangan teknologi informasi di perpustakaan, 5) Dalam kesibukan aktif bekerja di perpustakaan Pustakawan berusaha mencari informasi untuk meningkatkan kualitas pekerjaan yang dihasilkan. Hal ini menunjukkan bahwa indikator kompetensi yang membentuknya menurut responden atau pustakawan Pengadilan Agama di Sulawesi Selatan/Barat tergolong baik, artinya jika semua indikator variabel kompetensi tersebut dimaksimalkan oleh pustakawan, maka kinerja pustakawan akan meningkat. Indikator yang paling dominan membentuk variabel kompetensi adalah pengetahuan yang dimiliki pustakawan, memudahkan untuk melaksanakan tugas/pekerjaan pengelolaan perpustakaan. Hal ini menunjukkan bahwa rata-rata pustakawan telah memiliki 
pengetahuan di bidang perpustakaan, sehingga dapat menyelesaikan pekerjaan mengelola perpustakaan secara mandiri, ini terlihat juga bahwa pustakawan Pengadilan Agama di Sulawesi Selatan/Barat telah menempuh pendidikan sarjana (S1). Sedangkan pustakawan menganggap bahwa latar belakang pendidikan pustakawan berdampak dalam menyelesaikan tugas-tugasnya, memberikan porsi yang relatif rendah dalam membentuk kompetensi sehingga indikator ini perlu ditingkatkan agar kinerja pustakawan dapat dimaksimalkan. Selanjutnya bukti empiris yang mengaitkan kompetensi dengan kinerja pegawai menunjukkan hasil yang konsisten dengan studi ini, seperti penelitian Nurul Azmi (2019) bahwa kompetensi berpengaruh signifikan terhadap kinerja pegawai. Dengan demikian, temuan empiris yang dihasilkan dari penelitian ini adalah terdapat hubungan yang signifikan antara kompetensi dengan kinerja pustakawan.

\section{Pengaruh Motivasi Kerja terhadap Kinerja Pustakawan}

Hasil uji secara parsial dapat diketahui bahwa variabel motivasi kerja berpengaruh positif dan signifikan terhadap kinerja pustakawan Pengadilan Tinggi Agama di Sulawesi Selatan/Barat. Hal ini menunjukkan adanya hubungan yang searah antara motivasi kerja dengan kinerja pustakawan, dalam arti jika terjadi peningkatan motivasi kerja, maka kinerja pustakawan cenderung meningkat. Peningkatan variabel motivasi kerja ditentukan peran indikator pembentuknya yaitu : a. Fisiologi/Kebutuhan Fisik yang terdiri dari : 1) Gaji/pendapatan sebagai PNS/tenaga honorer telah membuat pegawai termotivasi bekerja, 2) Menjadi PNS/Honorer sudah membuat hidup menjadi lebih bahagia/senang, 3) Fasilitas sebagai PNS/Honorer seperti asuransi kesehatan, tunjangan, dapat memenuhi kebutuhan, $b$. Keamanan yang terdiri dari : 1) Kondisi ruang perpustakaan yang digunakan cukup aman, 2) Perlengkapan sarana dan prasarana perpustakaan cukup aman dan memadai digunakan baik oleh pemustaka maupun oleh pustakawan, 3) Keselamatan kerja di perpustakaan sudah diperhatikan dengan baik, c. Sosial yang terdiri dari : 1) Pustakawan dapat bersosialisasi dengan baik terhadap sesama rekan kerja di lingkungan kantor, 2) Hubungan kerja antara atasan dan bawahan baik dan tidak kaku, 3) Pustakawan sering ikut terlibat di dalam kegiatan-kegiatan kebersamaan yang dilakukan di luar kantor, d. Penghargaan yang terdiri dari : 1) Atasan memberikan penghargaan bagi bawahan yang berprestasi bilamana mampu menyelesaikan pekerjaan dengan baik dan tepat waktu, 2) Atasan memberikan pujian bila ada bawahan yang mampu menjalankan tugas pekerjaan dengan baik, 3) Atasan tidak menegur bawahan dengan kata atau kalimat yang kasar, 4) Pustakawan merasa saling menghormati dan menghargai antar sesama rekan kerja, d. Aktualisasi diri yang terdiri dari : 1) Atasan memberikan kesempatan kepada pustakawan mengikuti pelatihan untuk meningkatkan kemampuan dan keterampilan dalam mengelola perpustakaan, 2) Bekerja di perpustakaan membuat kemampuan pustakawan berkembang, 3) Saran dan kritik yang diberikan oleh atasan membuat pustakawan lebih maju. Hasil analisis deskriptif variabel motivasi kerja menunjukkan bahwa indikator keamanan dan aktualisasi diri memiliki skor paling rendah yaitu 3.96 tapi masih berada pada kategori baik. Indikator ini memberikan porsi terendah dalam membentuk variabel motivasi kerja sehingga perlu ditingkatkan agar kinerja pustakawan lebih maksimal. Adapun indikator yang dominan membentuk variabel motivasi kerja adalah faktor sosial yaitu pustakawan dapat bersosialisasi dengan baik terhadap sesama rekan kerja di lingkungan kantor. Hal ini menunjukkan bahwa pustakawan Pengadilan Agama di Sulawesi Selatan/Barat dapat memperlihatkan kinerja yang lebih maksimal itu didorong oleh karena hubungan yang baik antara sesama rekan kerja. Hal ini sejalan dengan penelitian yang dilakukan oleh Kusnadi Arifin (2018) menemukan bahwa motivasi kerja berpengaruh positif dan signifikan terhadap kinerja karyawan. Dengan demikian, temuan empiris dalam penelitian ini adalah terdapat hubungan yang siginifikan antara motivasi kerja dengan kinerja pustakawan.

\section{Pengaruh Lingkungan Kerja terhadap Kinerja Pustakawan}

Hasil uji parsial dapat diketahui bahwa variabel lingkungan kerja berpengaruh positif dan signifikan terhadap kinerja pustakawan Pengadilan Agama di Sulawesi Selatan/Barat. Hal ini menunjukkan adanya hubungan yang searah antara lingkungan kerja dengan kinerja pustakawan, dalam arti jika terjadi lingkungan kerja baik, maka kinerja pustakawan cenderung meningkat. Peningkatan variabel lingkungan kerja ditentukan oleh besarnya peran indikator yang membentuknya yaitu : a. suhu dan sirkulasi udara yang terdiri dari : 1) Suhu di ruang perpustakaan sudah cukup baik dan nyaman untuk menunjang aktivitas kerja pustakawan dan layanan kepada pemustaka, 2) Ventilasi udara yang ada di perpustakaan sudah cukup memadai, b. Penerangan/Pencahayaan yang terdiri dari 1) Perlengkapan penerangan lampu dalam ruang perpustakaan sudah baik dan memadai, 2) 
Pencahayaan sinar matahari dalam ruang perpustakaan tidak mengganggu koleksi dan aktivitas layanan, c. Ukuran ruang perpustakaan yang terdiri dari : 1) Ruangan yang disediakan oleh perpustakaan cukup luas, 2) Ruangan kerja pustakawan sekarang sudah membuat nyaman bekerja, $\mathrm{d}$. Tata letak ruang perpustakaan yang terdiri dari : 1) Posisi meja kerja dan meja baca di ruang perpustakaan sudah membuat pustakawan merasa nyaman, 2) Penempatan komputer dan sarana dan prasarana perpustakaan sudah membuat pustakawan nyaman bekerja dan melayani pemustaka, $\mathrm{d}$. Kebersihan dan suara bising yang terdiri dari : 1) Pustakawan merasa bila lingkungan kerja bersih membuat nyaman dalam bekerja dan melayani pemustaka, 2) Kebersihan lingkungan perpustakaan sudah dikelola dengan baik, 3) Tidak ada suara yang mengganggu di dalam ruang perpustakaan sehingga mempengaruhi aktivitas di perpustakaan, 4) Pustakawan merasa suasana yang ada di tempat kerja terasa cukup nyaman karena jauh dari suara bising, e. Penggunaan Warna \& Peralatan di Perpustakaan yang terdiri dari : 1) Pemilihan warna yang tepat dalam ruang perpustakaan dapat menimbulkan rasa nyaman, 2) Warna ruangan di perpustakaan sudah bagus dan tidak mengganggu dalam aktivitas kerja dan layanan pemustaka, 3) Jumlah unit komputer yang tersedia saat ini sudah cukup memadai untuk mendukung aktivitas di perpustakaan, 4) Fasilitas peralatan perpustakaan yang disediakan sudah cukup lengkap dan memadai, f. Keamanan kerja yang terdiri dari : 1) Kondisi keamanan yang memadai membuat pustakawan semangat bekerja, 2) Pustakawan merasa aman untuk meninggalkan ruangan, 3) Musik memberikan pengaruh posif dalam kegiatan di perpustakaan, g. Hubungan dengan sesama rekan kerja yang terdiri dari : 1) Hubungan antara sesama rekan kerja membantu pustakawan dalam bekerja, 2) Pustakawan mengganggap rekan kerja atau teman sekantor tidak hanya sebatas rekan kerja tapi sudah seperti bagian dari keluarga, 3) Hubungan antara sesama rekan kerja saling terbuka dalam berkomunikasi bila ada permasalahan atau konflik di lingkungan kerja, h. Hubungan Kerja Antara Atasan dan Bawahan yang terdiri dari : 1) Pimpinan di Pengadilan Agama memiliki hubungan yang baik dengan pustakawan, 2) Pimpinan di Pengadilan Agama dapat menciptakan suasana kerja yang kondusif, 3) Hubungan yang baik antara pimpinan di Pengadilan Agama dan pustakawan membantu dalam menyelesaikan masalah dalam pekerjaan yang ada di perpustakaan, 4) Pimpinan di Pengadilan Agama selalu memberikan dorongan, arahan, dan bimbingan kepada pustakawan untuk melaksanakan tugas dengan baik. Hasil analisis deskriptif variabel lingkungan kerja menunjukkan bahwa indikator yang paling dominan adalah kebersihan dan kebisingan dan hubungan kerja antara atasan dan bawahan. Pustakawan melihat bahwa kondisi ruang perpustakaan Pengadilan Agama cukup bersih dan tidak bising, begitupun hubungan kerja antara atasan dan bawahan di Pengadilan Agama cukup baik, sehingga lingkungan kerja pun cukup nyaman untuk bekerja. Sedangkan indikator suhu dan sirkulasi udara yang lancar, memberikan porsi yang relatif rendah dalam membentuk lingkungan kerja sehingga indikator ini perlu dimaksimalkan agar kinerja pustakawan dapat ditingkatkan.

Selanjutnya bukti empiris yang mengaitkan lingkungan kerja dengan kinerja pegawai menunjukkan hasil yang konsisten dengan studi ini, seperti penelitian Nur Gunawan Abdi (2018) bahwa lingkungan kerja berpengaruh signifikan terhadap kinerja pegawai. Dengan demikian, temuan empiris yang dihasilkan dari penelitian ini adalah terdapat hubungan yang signifikan antara lingkungan kerja dengan kinerja pustakawan. Berdasarkan hasil penelitian dan pembahasan yang telah diuraikan pada bagian sebelumnya, maka dapat ditarik kesimpulan sebagai berikut:

1. Secara simultan Kompetensi, Motivasi dan Lingkungan kerja berpengaruh positif terhadap Kinerja Pustakawan Pengadilan Agama di Sulawesi Selatan/Barat.

2. Kompetensi(X1) berpengaruh positif dan signifikan terhadap Kinerja Pustakawan Pengadilan Agama di Sulawesi Selatan/Barat.

3. Motivasi (X2) berpengaruh positif dan signifikan terhadap Kinerja Pustakawan Pengadilan Agama di Sulawesi Selatan/Barat.

4. Lingkungan kerja (X3) berpengaruh positif dan signifikan terhadap Kinerja Pustakawan Pengadilan Agama di Sulawesi Selatan/Barat.

\section{Saran}

Berdasarkan kesimpulan di atas, maka diajukan beberapa saran yang diharapkan dapat meningkatkan kinerja pustakawan Pengadilan Agama di Sulawesi Selatan Barat. Adapun saran-saran yang diberikan adalah sebagai berikut: (1) Untuk meningkatkan kinerja tenaga perpustakan Pengadilan Agama di Sulawesi Selatan maka Lembaga Pengadilan Agama dalam hal ini penentu 
kebijakan sebelum mengangkat pustakawan hendaknya mempertimbangkan latar belakang pendidikan yang sesuai dengan bidang perpustakaan atau memberi kesempatan kepada pegawai untuk mengikuti pendidikan atau pelatihan di bidang perpustakaan baik di lingkungan Pengadilan Agama maupun di instansi lain yang mengadakannya. Hal ini dapat dilihat berdasarkan Frekuensi Distribusi Jawaban dari variabel kompetensi salah satu indikator yaitu pendidikan mempunyai ratarata skor terendah. (2) Untuk meningkatkan kinerja pustakawan Pengadilan Agama di Sulawesi Selatan maka Lembaga Pengadilan Agama dalam hal ini penentu kebijakan perlu lebih memperhatikan kondisi ruang perpustakaan yang sarana dan prasarananya masih belum memadai, sehingga pustakawan kurang nyaman bekerja dengan kondisi ruang yang kurang memadai dan sarana prasarana yang seadanya sehingga tidak memenuhi standar perpustakaan khusus yang telah ditetapkan. (3) Untuk meningkatkan kinerja pustakawan Pengadilan Agama di Sulawesi Selatan/Barat maka Lembaga Pengadilan Agama dalam hal ini penentu kebijakan perlu memperhatikan kondisi lingkungan kerja pustakawan khususnya mengenai suhu dan sirkulasi udara ruang perpustakaan yang kurang memadai karena kebanyakan belum di lengkapi dengan pendingin ruangan (AC) sehingga pustakawan merasa kurang nyaman bekerja.

\section{DAFTAR PUSTAKA}

Abdi, Nur Gunawan. 2018. Pengaruh Kompetensi dan Lingkungan Kerja Terhadap Kinerja Pegawai Pada Dinas Kesehatan Kabupaten Kepulauan Selayar.

Abdurrahman. 2009. Makalah Peranan Perpustakaan Dalam Menunjang Pelaksanaan Tugas Peradilan. Mahkamah Agung RI. Jakarta

Arifin, Kusnadi. 2018. Pengaruh Kompetensi, Motivasi Kerja, dan Lingkungan Kerja Terhadap Kinerja Karyawan Pada PT Telkom Indonesia Wilayah Sulawesi Selatan (Studi kasus pada PT. Telkom Makassar STO Balaikota).

Azmi, Nurul. 2019. Pengaruh Motivasi, Komptensi dan Lingkungan Kerja Terhadap Kinerja Pegawai Kelurahan di Kecamatan Lalabata Kabupaten Soppeng.

Azwar, Saifuddin. 2009. Penyusunan Skala Psikologi. Pustaka Pelajar. Yogyakarta.

Bafadal, Ibrahim. 2003. Seri Manajemen Peningkatan Mutu Pendidikan Berbasis Sekolah, Manajemen Perlengkapan Sekolah Teori dan Aplikasi. Bumi Aksara. Jakarta.

Basalamah, M. S. A., \& As'ad, A. (2021). The Role of Work Motivation and Work Environment in Improving Job Satisfaction. Golden Ratio of Human Resource Management, 1(2), 94-103.

Bangun, Wilson, 2012. Manajemen Sumber Daya Manusia. Erlangga. Bandung

Bellizzi, J. A., Crowley, A. E., \& Hasty, R. W. (2000). The Effect of Color in Store Design. Journal of Retailing Vol. $59,21-45$.

Bello, M. M. (2021). The Terror Campaign of Boko Haram: Its Transformation and Challenges to Nigeria's Security. Golden Ratio of Social Science and Education, 1(2), 85-94.

Bustari, Meilina. 2000. Manajemen Perpustakaan Pendidikan. UNY Press. Yogyakarta.

Darsono dan Siswandoko. 2011. Sumber Daya Manusia Abad 21. Nusantara Consulting. Jakarta.

Harmawan. 2008. Peran Pustakawan Dalam Era Digitalisasi Informasi. https:/ library.uns.ac.id/tag/harmawan/. Pada 14 April 2020 Pukul 21.00 Wita.

Hasibuan, Malayu S.P. 2003. Manajemen Sumber Daya Manusia. Bumi Aksara. Edisi Revisi. Bandung.

Herzberg, Frederick, et.al. 2009. The Motivation to Work. USA : John Wiley \& Sons. Inc.

Izaak, Fitri Devi Lestari. 2019. Pengaruh Kepemimpinan. Lingkungan Kerja dan Motivasi Terhadap Kinerja Karyawan Pada PT Garuda Indonesia Bandar Udara Sultan Hasanuddin.

Jumady, E., \& Lilla, L. (2021). Antecedent and Consequence the Human Resources Management Factors on Civil Servant Performance. Golden Ratio of Human Resource Management, 1(2), 104-116.

Liestyodono dan Purwaningdyah. 2008. Meningkatkan Kompetensi Aparatur Pemerintah Daerah Dalam Mewujudkan Good Governance. Jurnal Kebijakan dan Manajemen PNS Pusat Pengkajian dan Penelitian Kepegawaian BKN.

Mahkamah Agung RI. 2016. Pedoman Penyelenggaraan dan Pengelolaan Perpustakaan Mahkamah Agung RI : Sebagai Acuan dalam Penyelenggaraan Perpustakaan Pengadilan Tingkat Banding dan Pengadilan Tingkat Pertama. Biro Hukum dan Humas Badan Urusan Administrasi Mahkamah Agung Republik Indonesia. Jakarta.

Mahkamah Agung RI. 2016. Standar Perpustakaan Khusus Mahkamah Agung Republik Indonesia dan Empat Lingkungan Peradilan. Biro Hukum dan Humas Badan Urusan Administrasi Mahkamah Agung Republik Indonesia. Jakarta.

Mahdalena, M., \& Said, D. (2021). Budget Accountability in The Perspective of Habermas Communicative Action Theory. Golden Ratio of Social Science and Education, 1(2), 61-72.

Mangkunegara, A. A, Anwar Prabu, 2006. Evaluasi Kinerja Sumber Daya Manusia. Refika Aditama. Bandung. Mangkuprawira, TB Safri. 2003. Manajemen Sumber Daya Manusia Strategik. Ghalia Indonesia. Jakarta. 
Mulang, H. (2021). The Effect of Competences, Work Motivation, Learning Environment on Human Resource Performance. Golden Ratio of Human Resource Management, 1(2), 84-93.

Nitisemito, Alex. 2011. Manajemen Sumber Daya Manusia. Ghalia Indonesia. Jakarta.

Perpustakaan Nasional. 2006. Pedoman Umum Penyelenggaraan Perpustakaan Khusus. Perpustakaan Nasional. Jakarta.

Permatasari, N., Anwar, S. R., \& Rustham, A. T. P. (2021). The Relationship Between Perceived Emotional Intelligence and Late Adolescent Autonomy. Golden Ratio of Social Science and Education, 1(2), $73-84$.

Permatasari, N., Ashari, F. R., \& Ismail, N. (2021). Contribution of Perceived Social Support (Peer, Family, and Teacher) to Academic Resilience during COVID-19. Golden Ratio of Social Science and Education, 1(1), 0112.

Rais, Muhammad Amin. 2021. Pengaruh Pelayanan dan Kompetensi Terhadap Kinerja Komisioner Komisi Penegakan Kode Etik Universitas Islam Negeri Alauddin Makassar.

Robbins, Stephen R. 2002. Perilaku Organisasi Konsep, Kontroversi dan Aplikasi, (Versi Bahasa Iindonesia), Edisi Kedelapan, Prenhhalindo. Jakarta.

Sarwono, Sarlito Wirawan. 2005. Psikologi Lingkungan. Gramedia Grasindo. Jakarta.

Sedarmayanti. 2007. Manajemen Sumber Daya Manusia. Refika Aditama. Bandung.

Setiawan, Ferry dan Dewi, Kartika. 2014. Pengaruh Kompensasi dan Lingkungan Kerja terhadap Kinerja Karyawan pada CV. Berkat Anugrah. Jurnal. Universitas Udayana. Denpasar.

Siagian, Sondang P. 2011. Manajemen Sumber Daya Manusia. Bumi Aksara. Jakarta.

Sihombing, Umberto. 2001. Pengaruh Keterlibatan Dalam Pengambilan Keputusan, Penilaian pada Lingkungan Kerja dan Motivasi Berprestasi Terhadap Kepuasan Kerja Pamong Praja. http:/ /www. Dupdiknas.go.ig.

Simamora, Henry. 2001. Manajemen Sumber Daya Manusia. STIE YKPN. Yogyakarta.

Simanjuntak, Payaman J. 2005. Manajemen dan Evaluasi Kinerja. Lembaga Penerbit Fakultas Ekonomi UI. Jakarta.

Sitopu, Y. B., Sitinjak, K. A., \& Marpaung, F. K. (2021). The Influence of Motivation, Work Discipline, and Compensation on Employee Performance. Golden Ratio of Human Resource Management, 1(2), 72-83.

Sitorus, D. S., Putri, A. A., Hidayat, P. R., \& Rostina, C. F. (2021). The Influence of Selection, Motivation and Utilization of Information System Academic for Lecturer (SIAD) on the Lecturer Performance. Golden Ratio of Human Resource Management, 1(2), 61-71.

Soetjiptto, Budi W. 2002. Paradigma Baru Manajemen Sumber Daya Manusia. Amara Books. Yogyakarta.

Soetminah. 1992. Perpustakaan Kepustakawanan dan Pustakawan. Kanisius. Yogyakarta.

Sudarmanto. 2009. Kinerja dan Pengembangan Kompetensi SDM Teori, Dimensi dan Implementasi dalam Organisasi. Pustaka Pelajar. Yogyakarta.

Sukanto Reksohadiprojo dan Indriyo Gitosudarmo. 2000. Manajemen Produksi. BPEE UGM. Yogyakarta.

Surachman, Arif. 2009. Pustakawan Asia Tenggara Menghadapi Globalisasi dan Pasar Bebas. http:/ / eprint.rclis.0rg/17554/. Pada 14 April 2020 Pukul 20.00 Wita.

Sutrisno, Edy. 2012. Manajemen Sumber Daya Manusia. Predana Media Group. Jakarta.

Taufik, Muhammad Ahyaul Fitra. 2018. Pengaruh Kompetensi, Disiplin Kerja, dan Lingkungan Kerja Terhadap Kinerja Pegawai Negeri Sipil pada Biro Bina Kesejahteraan Provinsi Sulawesi Selatan.

Undang-undang No. 43 Tahun 2007 tentang Perpustakaan. 2007. Perpustakaan Nasional RI. Jakarta.

Wahid, Subondo. 2004. Manajemen Sumber Daya Manusia. Bina Ilmu. Solo.

Wibowo. 2012. Manajemen Kinerja. Raja Grafindo Persada. Jakarta.

Wirawan. 2009. Evaluasi Kinerja Sumber Daya Manusia : Teori Aplikasi dan Penelitian. Salemba Empat. Jakarta.

Zwell, Michael. 2000. Creating a Culture of Competence. John Wiley \& Sons. Inc. New York. 